\title{
SUBTASK 3.16 - LOW-BTU OIL FIELD GAS APPLICATION TO MICROTURBINES
}

\author{
Final Report \\ (for the period of April 1, 2006, through June 30, 2007) \\ Prepared for: \\ AAD Document Control \\ U.S. Department of Energy \\ National Energy Technology Laboratory \\ 626 Cochrans Mill Road \\ PO Box 10940, MS 921-107 \\ Pittsburgh, PA 15236-0940 \\ Cooperative Agreement No. DE-FC26-98FT40320 \\ Project Manager: Donald Geiling
}

Prepared by:

Darren D. Schmidt Benjamin G. Oster

Energy \& Environmental Research Center University of North Dakota 15 North 23rd Street, Stop 9018

Grand Forks, ND 58202-9018 


\section{DISCLAIMER}

This report was prepared as an account of work sponsored by an agency of the United States Government. Neither the United States Government, nor any agency thereof, nor any of their employees makes any warranty, express or implied, or assumes any legal liability or responsibility for the accuracy, completeness, or usefulness of any information, apparatus, product, or process disclosed or represents that its use would not infringe privately owned rights. Reference herein to any specific commercial product, process, or service by trade name, trademark, manufacturer, or otherwise does not necessarily constitute or imply its endorsement, recommendation, or favoring by the United States Government or any agency thereof. The views and opinions of authors expressed herein do not necessarily state or reflect those of the United States Government or any agency thereof.

This report is available to the public from the National Technical Information Service, U.S. Department of Commerce, 5285 Port Royal Road, Springfield, VA 22161; phone orders accepted at (703) 487-4650.

\section{EERC DISCLAIMER}

LEGAL NOTICE: This research report was prepared by the Energy \& Environmental Research Center (EERC), an agency of the University of North Dakota, as an account of work sponsored by the U.S. Department of Energy. Because of the research nature of the work performed, neither the EERC nor any of its employees makes any warranty, express or implied, or assumes any legal liability or responsibility for the accuracy, completeness, or usefulness of any information, apparatus, product, or process disclosed or represents that its use would not infringe privately owned rights. Reference herein to any specific commercial product, process, or service by trade name, trademark, manufacturer, or otherwise does not necessarily constitute or imply its endorsement or recommendation by the EERC. 


\title{
SUBTASK 3.16 - LOW-BTU OIL FIELD GAS APPLICATION TO MICROTURBINES
}

\begin{abstract}
Low-energy gas at oil production sites presents an environmental challenge to the sites' owners. Typically, the gas is managed in flares. Microturbines are an effective alternative to flaring and provide on-site electricity. Microturbines release 10 times fewer $\mathrm{NO}_{\mathrm{x}}$ emissions than flaring, on a methane fuel basis. ${ }^{1}$ The limited acceptable fuel range of microturbines has prevented their application to low-Btu gases. The challenge of this project was to modify a microturbine to operate on gases lower than $350 \mathrm{Btu} / \mathrm{scf}$ (the manufacturer's lower limit). The Energy \& Environmental Research Center successfully operated a Capstone C30 microturbine firing gases between 100-300 Btu/scf. The microturbine operated at full power firing gases as low as $200 \mathrm{Btu} / \mathrm{scf}$. A power derating was experienced firing gases below $200 \mathrm{Btu} / \mathrm{scf}$. As fuel energy content decreased, $\mathrm{NO}_{\mathrm{x}}$ emissions decreased, $\mathrm{CO}$ emissions increased, and unburned hydrocarbons remained less than $0.2 \mathrm{ppm}$. The turbine was self-started on gases as low as 200 Btu/scf. These results are promising for oil production facilities managing low-Btu gases. The modified microturbine provides an emission solution while returning valuable electricity to the oilfield.
\end{abstract}

\footnotetext{
${ }^{1}$ Compilation of Air Pollutant Emission Factors, Volume 1: Stationary Point and Area Sources, Chapter 2.4, November 1998; Product Data Sheet, C30 Natural Gas Microturbine Performance Specifications, Capstone Turbine Corporation.
} 


\section{TABLE OF CONTENTS}

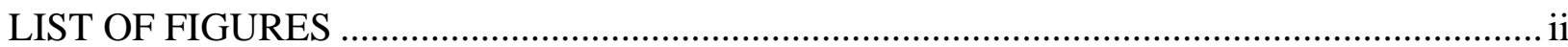

EXECUTIVE SUMMARY …………………………......................................................... iii

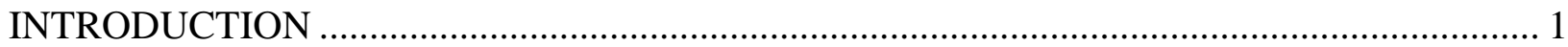

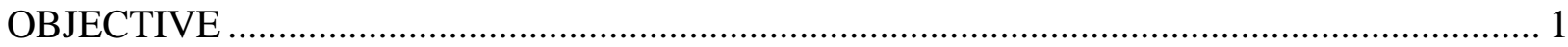

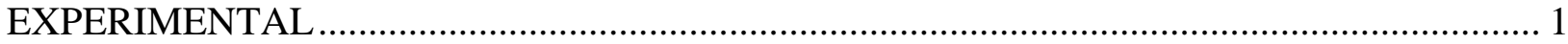

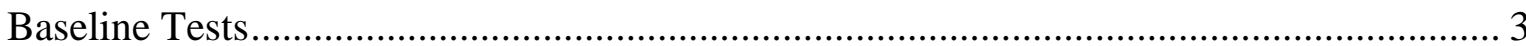

External Combustor Tests .................................................................................... 3

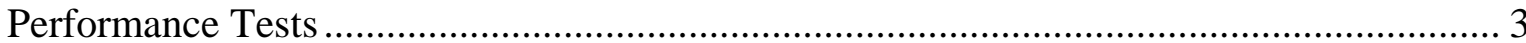

Ignition Tests ......................................................................................................... 3

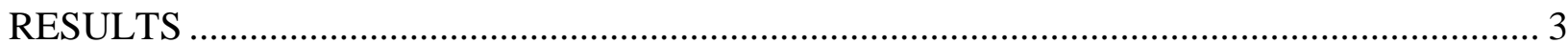

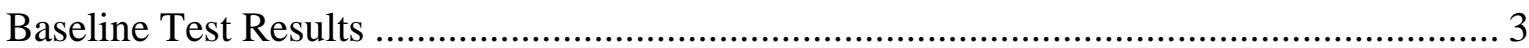

External Combustor Test Results .................................................................................... 3

Performance Test Results....................................................................................... 5

Ignition Test Results................................................................................................. 5

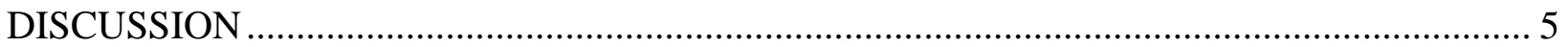

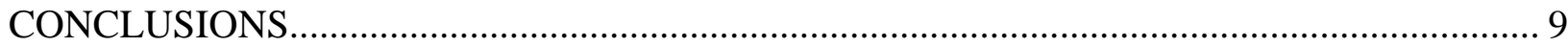

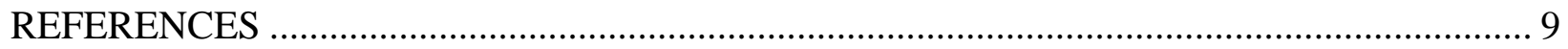

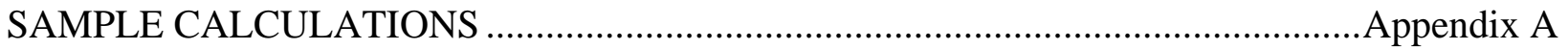

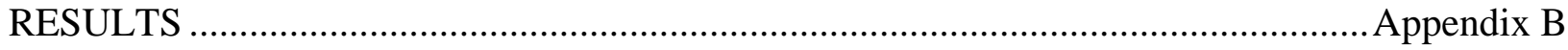




\section{LIST OF FIGURES}

1 Baseline microturbine $\mathrm{NO}_{\mathrm{x}}$ emissions compared to flare $\mathrm{NO}_{\mathrm{x}}$ emissions ........................ 1

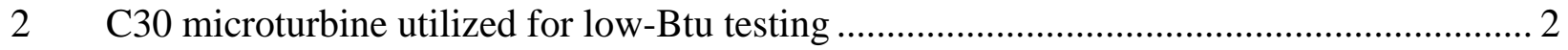

3 Flame exiting the external test combustor................................................................ 2

4 FTIR values compared to flow rate calculated values ............................................... 4

5 Fuel mixture inside the injector compared to upper and lower flammability limits ............ 4

6 Fuel mixture at the injector exit compared to upper and lower flammability limits............ 6

7 Gas velocity inside of the injector and at the injector exit compared to the maximum flame speed of methane and low caloric value (LCV) gas.......................................... 6

8 Modifications allowed a C30 microturbine to operate on gases lower than the baseline

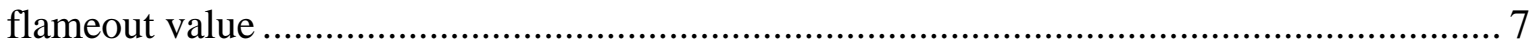

$9 \quad \mathrm{NO}_{\mathrm{x}}$ emissions decreased as fuel heating value decreased ........................................... 7

10 CO emissions increased as fuel heating value decreased ......................................... 8

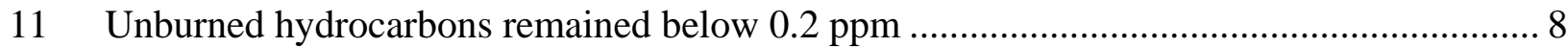




\section{SUBTASK 3.16 - LOW-BTU OIL FIELD GAS APPLICATION TO MICROTURBINES}

\section{EXECUTIVE SUMMARY}

Carbon emissions and clean air concerns will continue to drive more stringent environmental legislation. As oil companies seek traditional solutions for lowering emissions from associated gas, energy production from microturbines is emerging as a potential economic solution. This project explored the potential application of microturbines to low-Btu gas.

Many oil production sites contain and flare millions of cubic feet of associated gas daily. The barrier to microturbine applications in many oil field applications is the manufacturer's lower energy limit of $350 \mathrm{Btu} / \mathrm{scf}$. The objective of this project was to modify a Capstone C30 microturbine to operate on gases lower than $350 \mathrm{Btu} / \mathrm{scf}$. Breaking the lower energy barrier unlocks many opportunities previously considered infeasible.

A C30 Capstone microturbine was modified and tested at the Energy \& Environmental Research Center. The microturbine was operated firing gases between 100-300 Btu/scf. The microturbine operated at full power firing gases as low as $200 \mathrm{Btu} / \mathrm{scf}$. A power derating was experienced firing gases below $200 \mathrm{Btu} / \mathrm{scf}$. As fuel energy content decreased, $\mathrm{NO}_{\mathrm{x}}$ emissions decreased, CO emissions increased, and unburned hydrocarbons remained below $0.2 \mathrm{ppm}$. A catalytic converter can reduce $\mathrm{CO}$ for sites where $\mathrm{CO}$ emissions are a concern. The turbine achieved self-ignition on $200 \mathrm{Btu} / \mathrm{scf}$ gas. On-site start-up fuel (example: a natural gas line or storage tank) would provide an energy rich ignition source before switching to low-Btu gas.

These results are very promising for oil producers. Microturbines produced power from gases below the lower energy barrier. Low-energy flare gas can be used to create electricity while reducing emissions. 


\section{SUBTASK 3.16 - LOW-BTU OIL FIELD GAS APPLICATION TO MICROTURBINES}

\section{INTRODUCTION}

This study determined modifications that allow microturbines to operate on low-Btu gas. Many oil production sites contain abundant amounts of low-Btu associated gas. This gas is often burned in a flare. Typically, flares release 10 times the amount of $\mathrm{NO}_{\mathrm{x}}$ that microturbines do, based on a methane fuel $(1,2)$. A baseline comparison is shown in Figure 1. Microturbines produce on-site electrical power; however, a $350 \mathrm{Btu} / \mathrm{scf}$ lower energy specification has limited their application to low-Btu gases.

\section{OBJECTIVE}

The objective of this project was to modify a commercially available microturbine to operate on low-Btu gas.

\section{EXPERIMENTAL}

The test apparatus included a C30 microturbine, a fuel supply system, and an external combustion can. The test procedure consisted of four tests: baseline tests, external combustor tests, performance tests, and ignition tests. A picture and a graphic of the test microturbine are shown in Figure 2. Figure 3 shows a flame exiting the external test combustor.

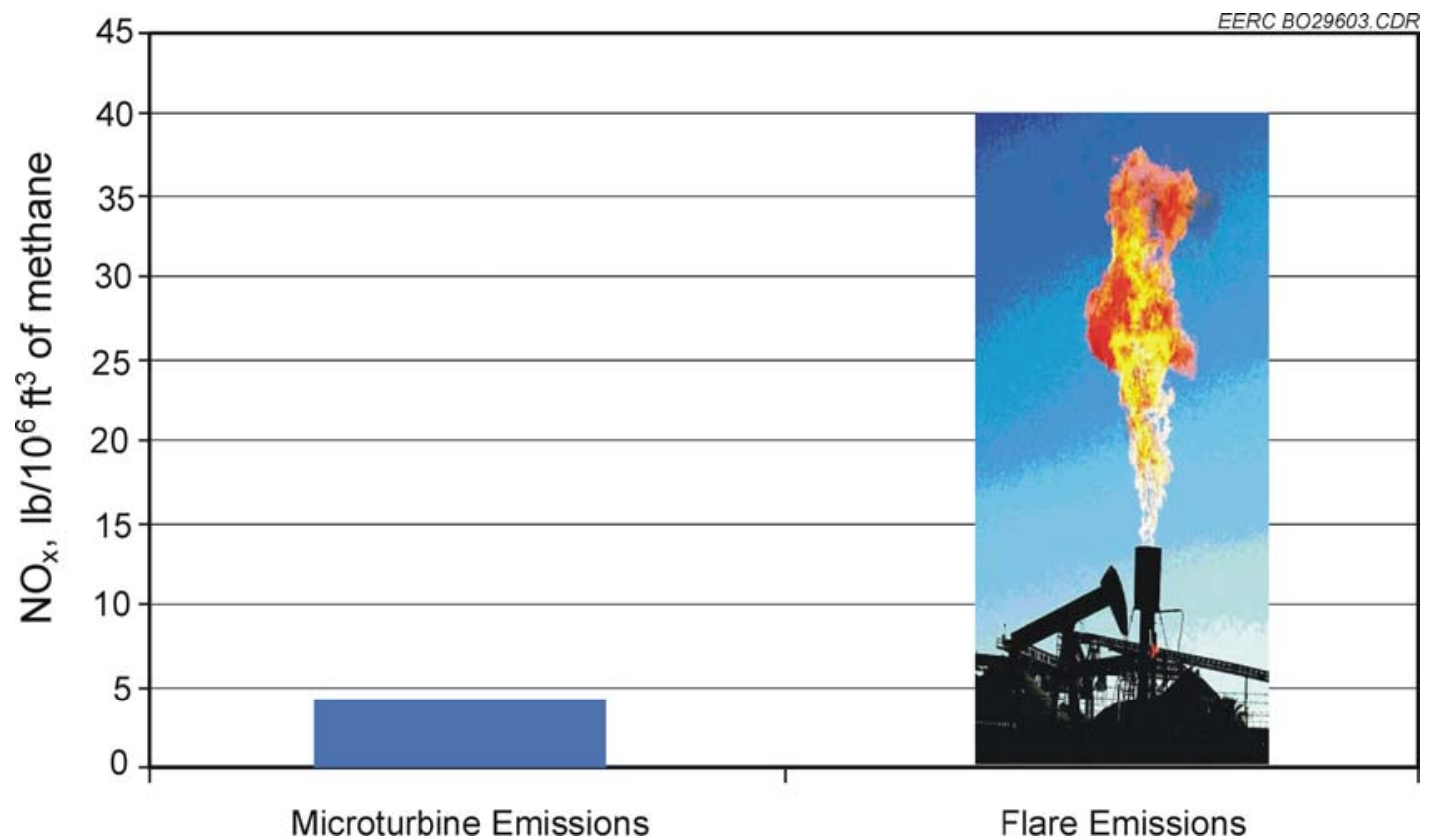

Figure 1. Baseline microturbine $\mathrm{NO}_{\mathrm{x}}$ emissions compared to flare $\mathrm{NO}_{\mathrm{x}}$ emissions $(3,4)$. 

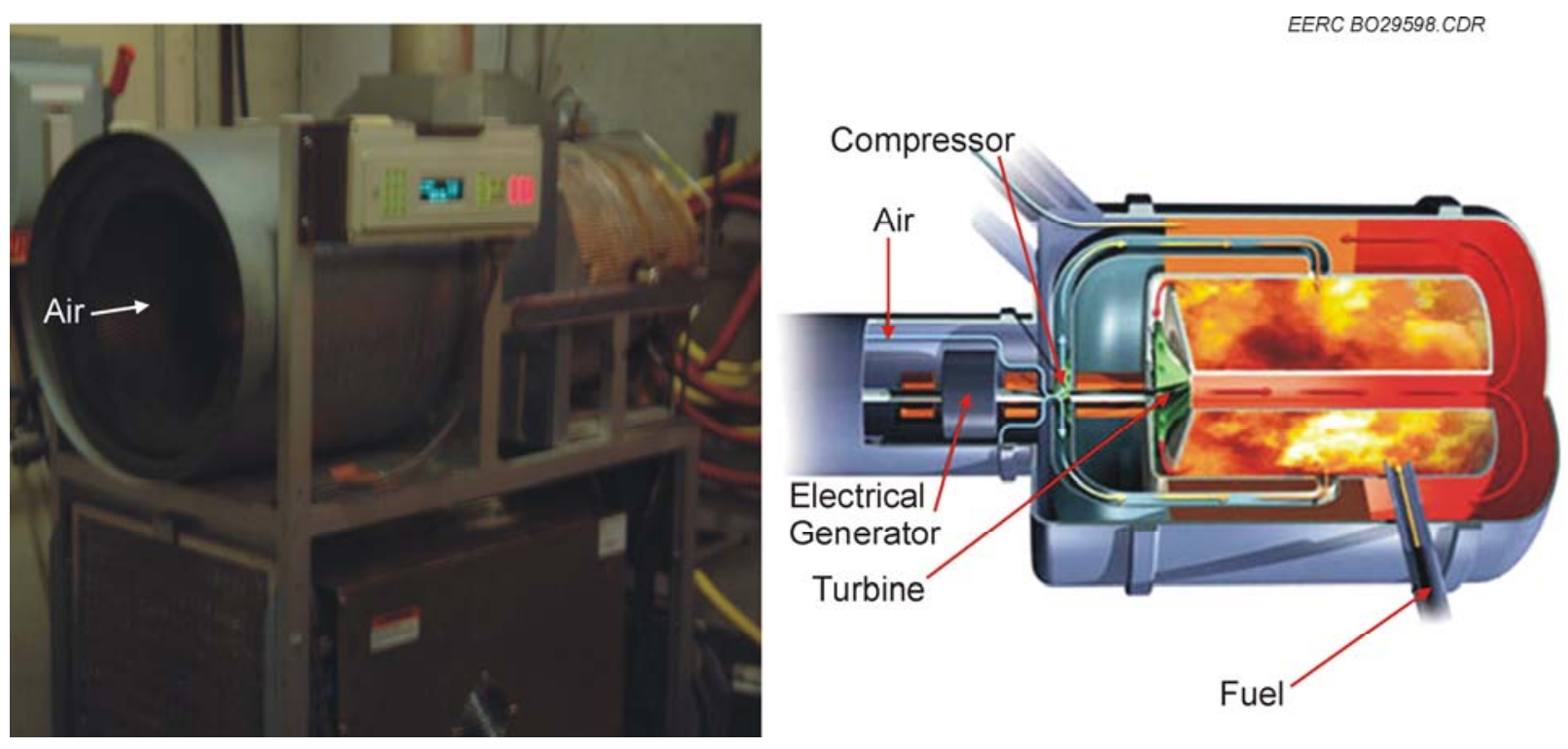

Figure 2. C30 microturbine utilized for low-Btu testing (3).

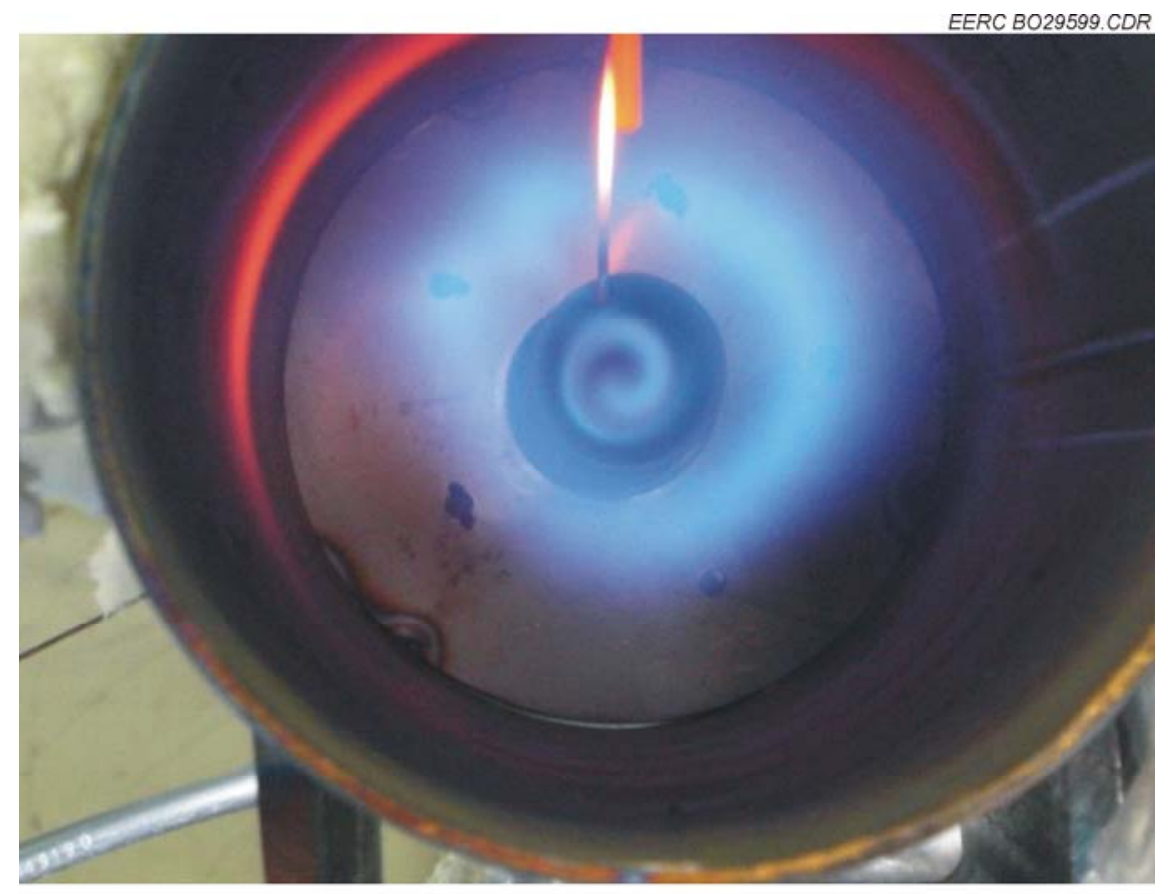

Figure 3. Flame exiting the external test combustor. 


\section{Baseline Tests}

Baseline tests utilized the C30 microturbine and the fuel supply system. The fuel supply system blended natural gas and nitrogen upstream of the microturbine. A rotameter measured flow and a digital pressure gauge measured pressure in each line. Natural gas and nitrogen flow rates allowed energy density to be calculated, as shown in Appendix A. The inlet gas mixture was diluted with nitrogen until the microturbine failed to operate. Fourier Transform Infrared Spectroscopy (FTIR) measurements were compared to flow calculated heating values. FTIR measured the absorbance of light in the inlet gas stream and related the absorbance to that of known compounds. The known energy density of the known compounds was used to determine energy density.

\section{External Combustor Tests}

External combustor tests were conducted in an external combustion can. Air and gas flow measurements were recorded and the fuel injector flame location was observed. External tests gathered necessary information for microturbine modifications.

\section{Performance Tests}

Performance tests utilized modified microturbine parts in a C30 microturbine. Nitrogen diluted the inlet gas mixture until the microturbine failed to operate. A Landcom III portable gas analyzer measured emissions as fuel energy content decreased. Two modifications were tested.

\section{Ignition Tests}

Ignition tests utilized the C30 microturbine and a premixed gas mixture of nitrogen and natural gas. Nitrogen and natural gas were combined in a tank before each test. Start-up attempts on low-Btu gas were conducted with various gas mixtures.

\section{RESULTS}

\section{Baseline Test Results}

The unmodified microturbine failed to operate at 300 Btu/scf. FTIR-calculated gas energy values agreed closely to flow-rate calculated values, as shown in Figure 4. Other FTIR test results are shown in Appendix B.

\section{External Combustor Test Results}

External tests provided stoichiometry and flame speed information. Conditions inside the fuel injector were too rich for combustion. Figure 5 shows operating conditions inside the injector compared to upper and lower flammability limits. Inside the injector, fuel velocity was greater than the flame speed of methane. 


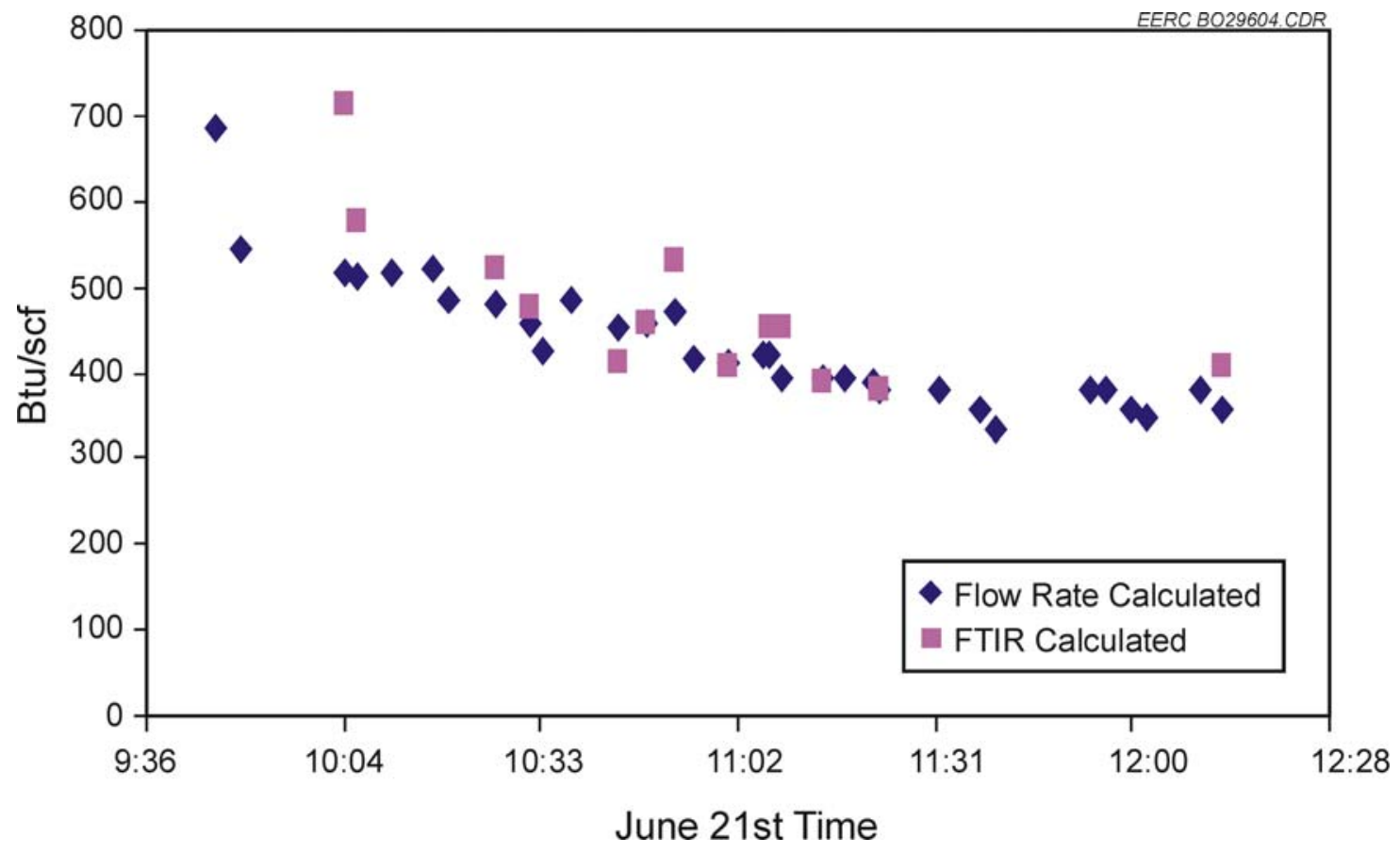

Figure 4. FTIR values compared to flow rate calculated values.

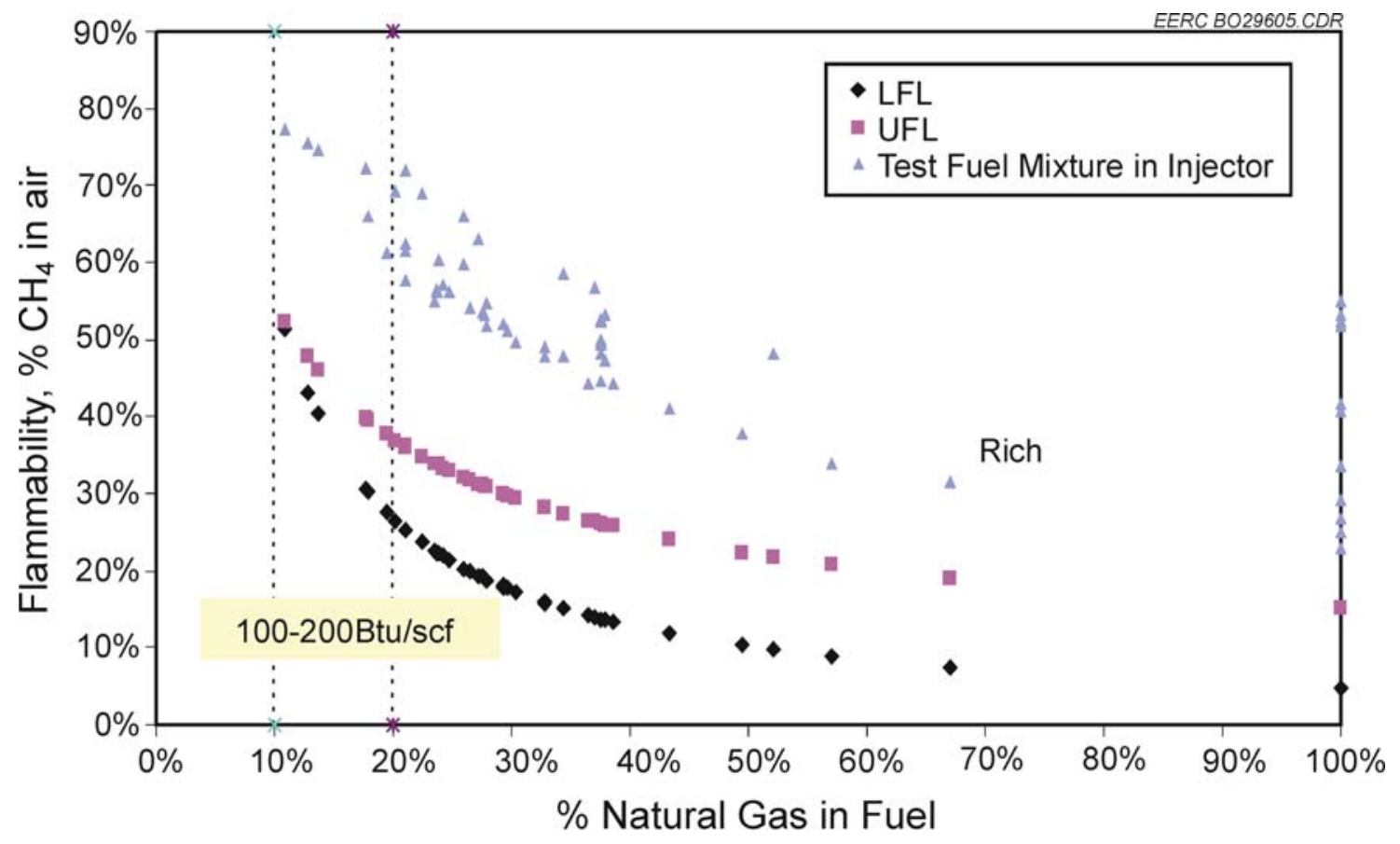

Figure 5. Fuel mixture inside the injector compared to upper and lower flammability limits. 
Conditions at the injector exit were suitable for combustion. Figure 6 compares conditions at the injector exit to upper and lower flammability limits. Velocities inside the injector and at the injector exit are shown in Figure 7.

\section{Performance Test Results}

Modifications allowed the microturbine to operate on low-Btu gas. Figure 8 compares baseline operations to operations with Modification 1 and Modifications 1 and 2.

The unmodified microturbine was limited to a heating value of $300 \mathrm{Btu} / \mathrm{scf}$ and could not fire gases diluted further. Modifications enabled the turbine to operate below $300 \mathrm{Btu} / \mathrm{scf}$. A power derating was experienced firing gases below $200 \mathrm{Btu} / \mathrm{scf}$, and further modification was required to achieve combustion in the 100-150 Btu/scf range.

The microturbine produced $26 \mathrm{~kW}$ from $175 \mathrm{Btu} / \mathrm{scf}$ fuel when Modification 1 was installed. During testing, the microturbine recovered from a temporary fuel energy decrease to $139 \mathrm{Btu} / \mathrm{scf}$.

The microturbine produced $20 \mathrm{~kW}$ of power from $150 \mathrm{Btu} / \mathrm{scf}$ gas for 37 minutes when Modifications 1 and 2 were installed. The microturbine recovered from a temporary fuel decrease to $101 \mathrm{Btu} / \mathrm{scf}$. When gas energy content was permanently decreased to $133 \mathrm{Btu} / \mathrm{scf}$, the microturbine shut down.

$\mathrm{NO}_{\mathrm{x}}$ emissions decreased with increased nitrogen dilution. Unburned hydrocarbons $\left(\mathrm{C}_{\mathrm{x}} \mathrm{H}_{\mathrm{y}}\right)$ remained below $0.2 \mathrm{ppm}$. Carbon monoxide emissions increased with increased nitrogen dilution. Emissions are summarized in Figures 9-11.

\section{Ignition Test Results}

The microturbine was able to self-ignite on gases down to 200 Btu/scf. Below 200 Btu/scf, the microturbine did not self-ignite.

\section{DISCUSSION}

Tests supported the hypothesis that microturbines can be modified to operate on low-Btu gases. Emission changes were not unmanageable. CO emissions increased with decreasing fuel energy content. Catalytic converters are known to reduce CO emissions. Unburned hydrocarbons remained below $0.2 \mathrm{ppm}(0.0005 \mathrm{lb} / \mathrm{hr})$. A small U.S. 4-cylinder 1997 passenger car equipped with a 3-way catalyst and traveling $60 \mathrm{mph}$ typically produces $0.033 \mathrm{lb} / \mathrm{hr}$ of hydrocarbons (2, 6, 7). These numbers suggest that microturbines emit 66 times fewer unburned hydrocarbons than a typical automobile. 


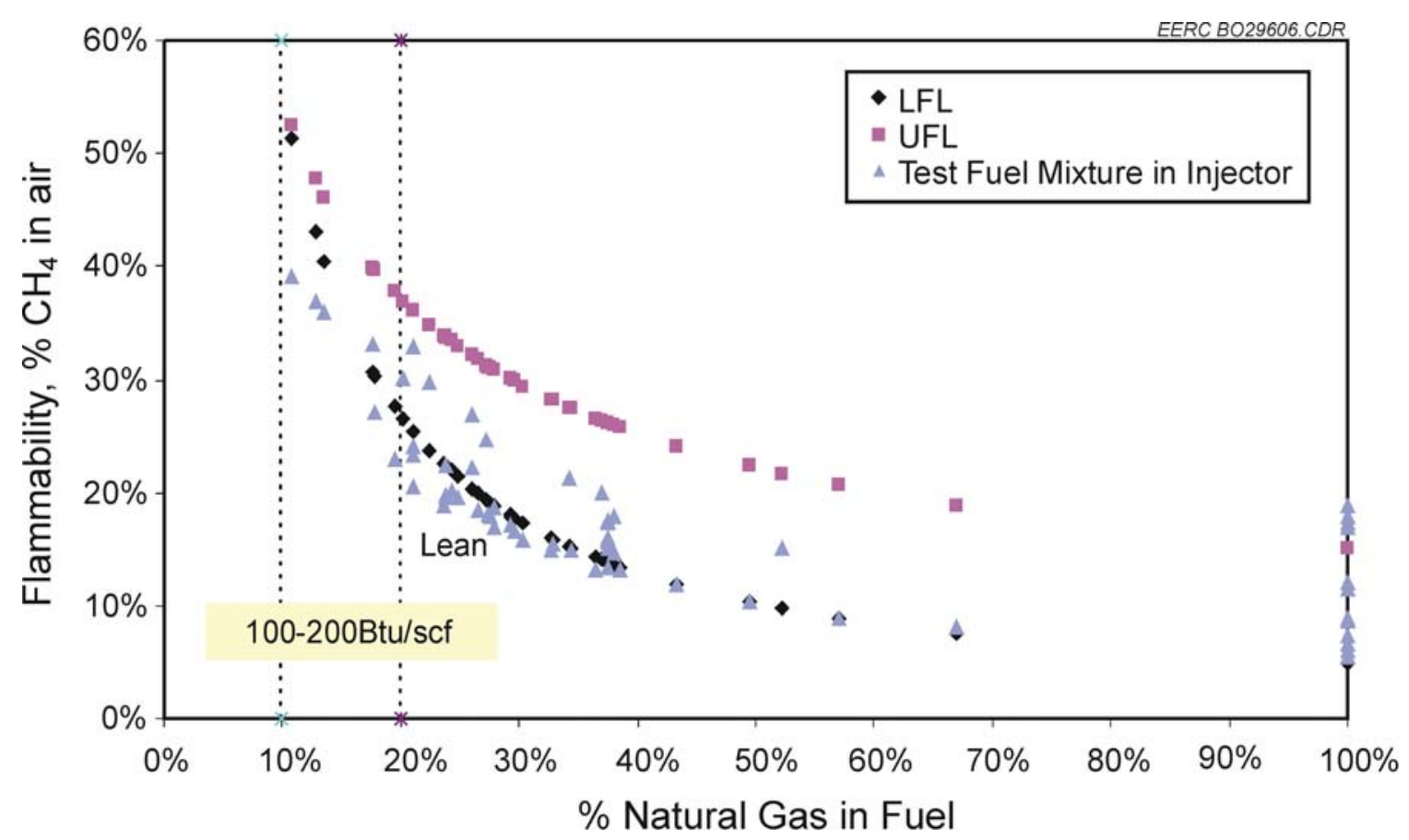

Figure 6. Fuel mixture at the injector exit compared to upper and lower flammability limits.

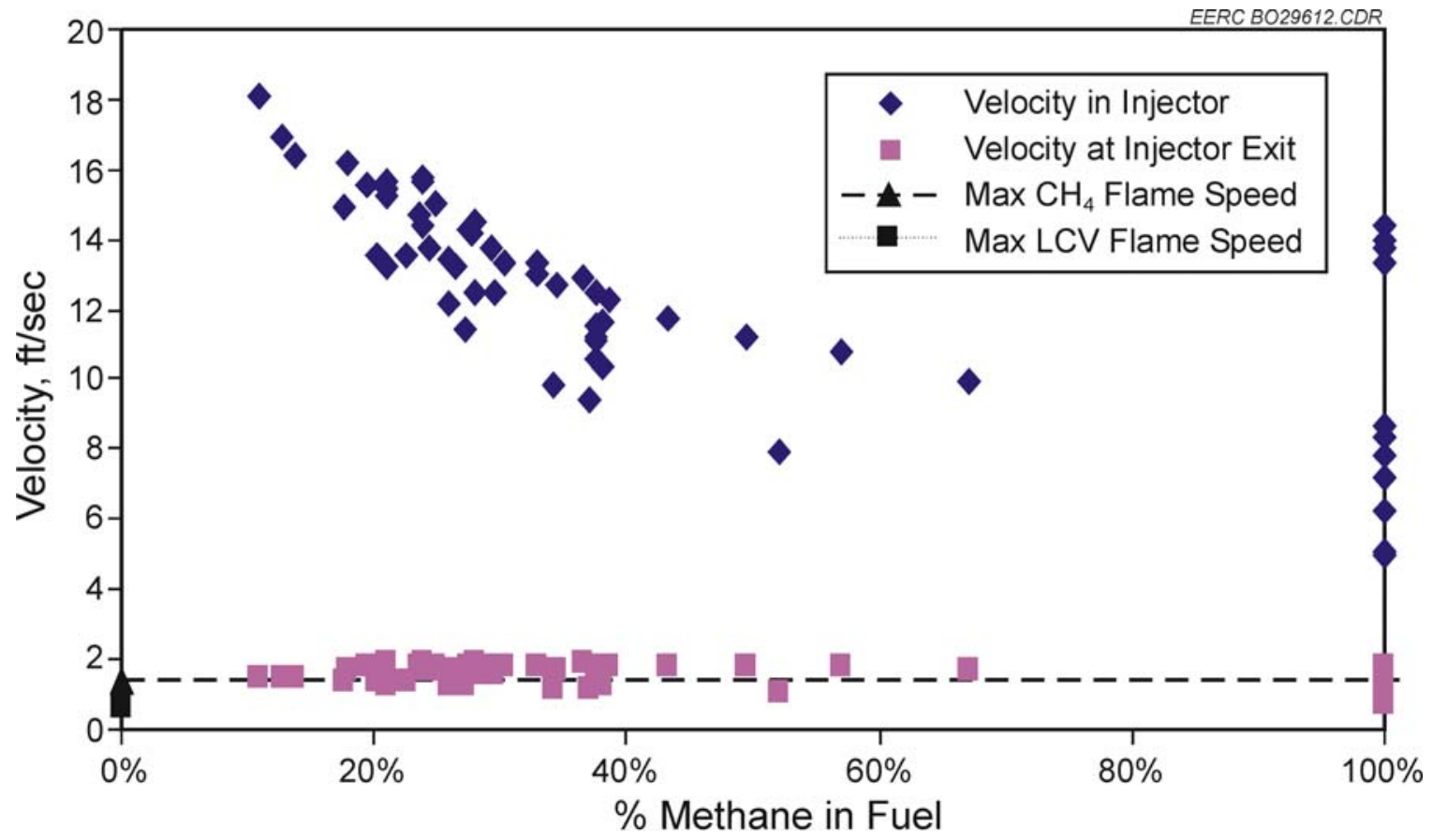

Figure 7. Gas velocity inside of the injector and at the injector exit compared to the maximum flame speed of methane and low caloric value (LCV) gas. 


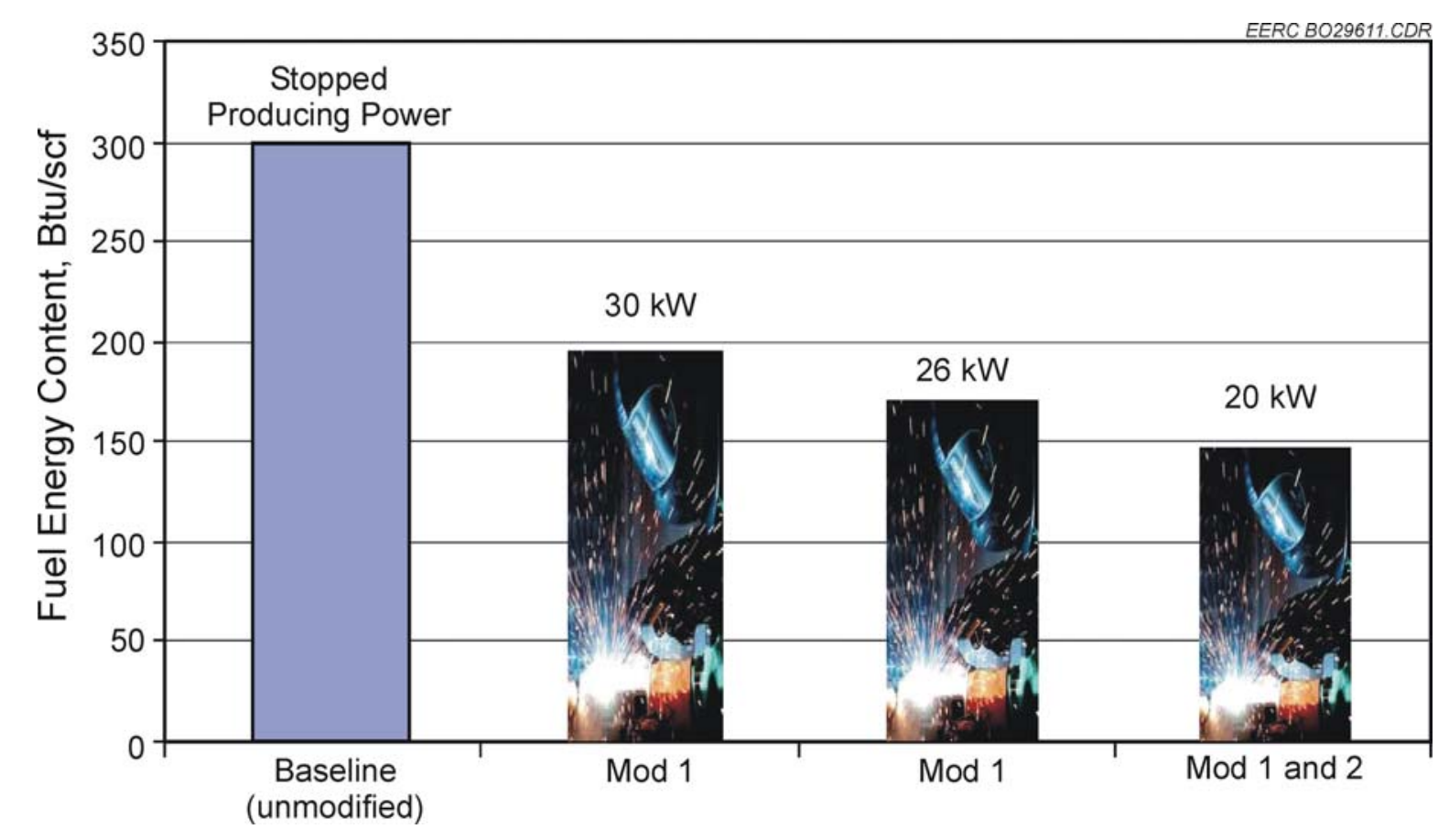

Figure 8. Modifications allowed a C30 microturbine to operate on gases lower than the baseline flameout value (5).

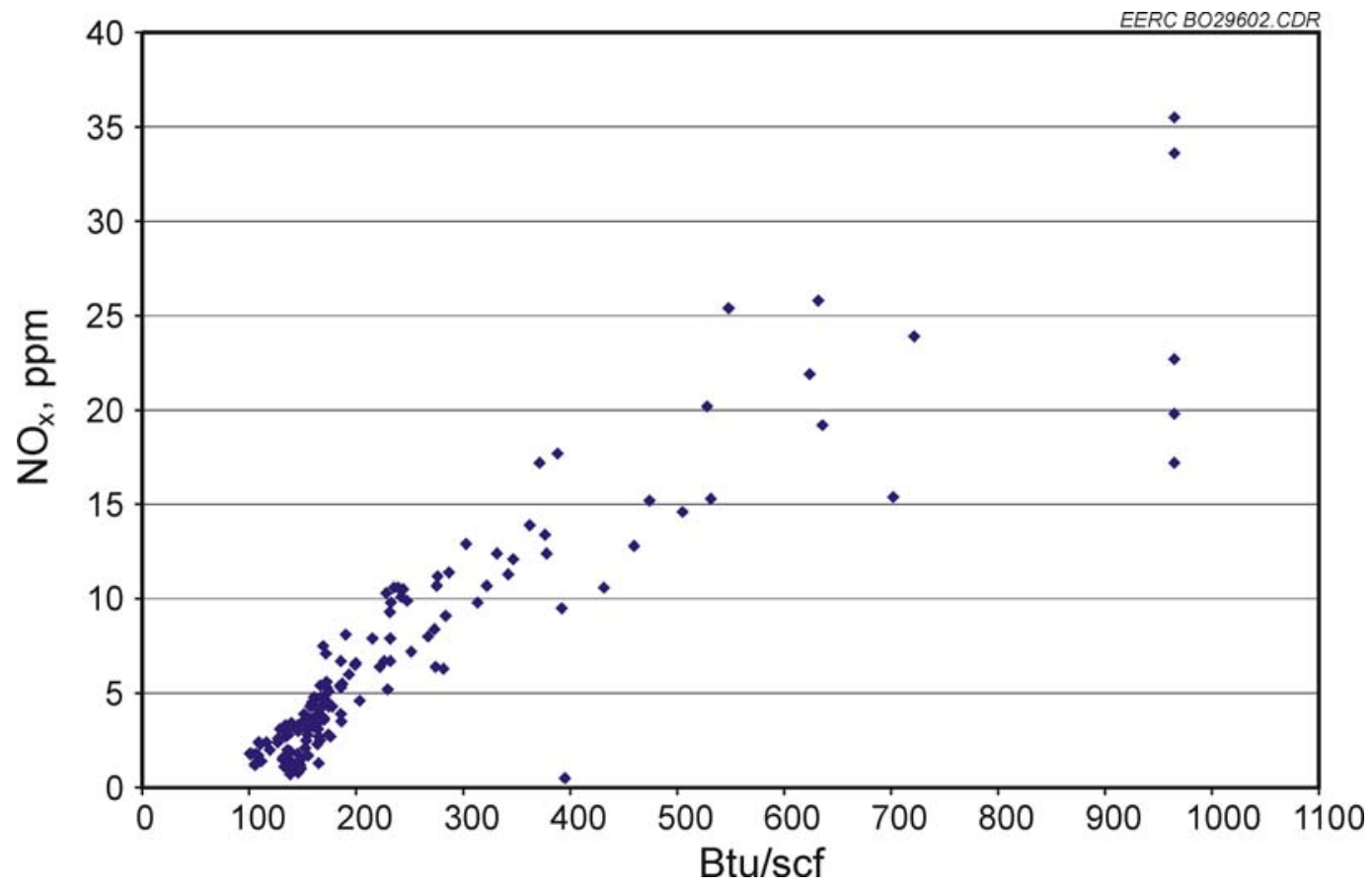

Figure 9. $\mathrm{NO}_{\mathrm{x}}$ emissions decreased as fuel heating value decreased. 


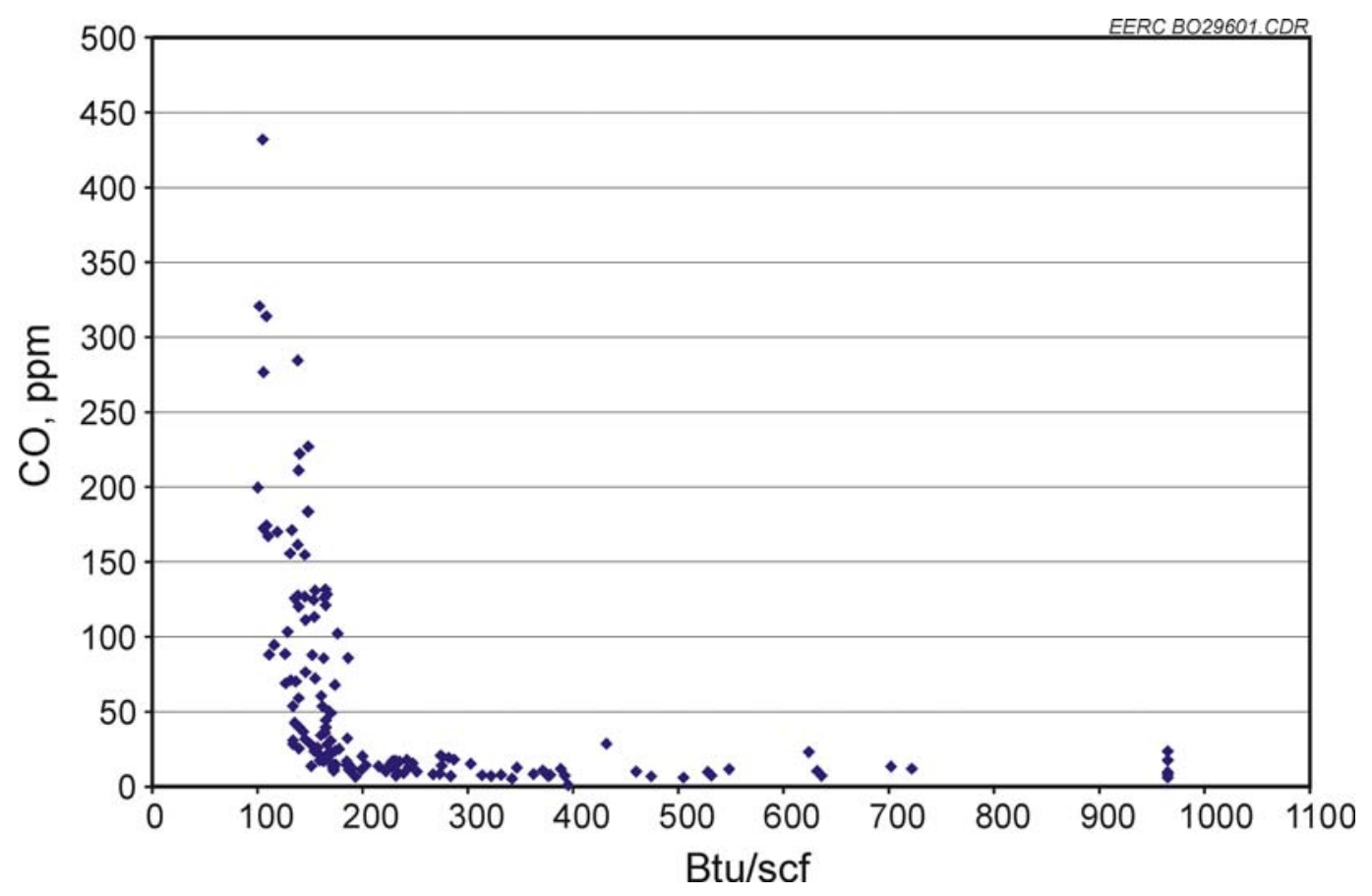

Figure 10. CO emissions increased as fuel heating value decreased.

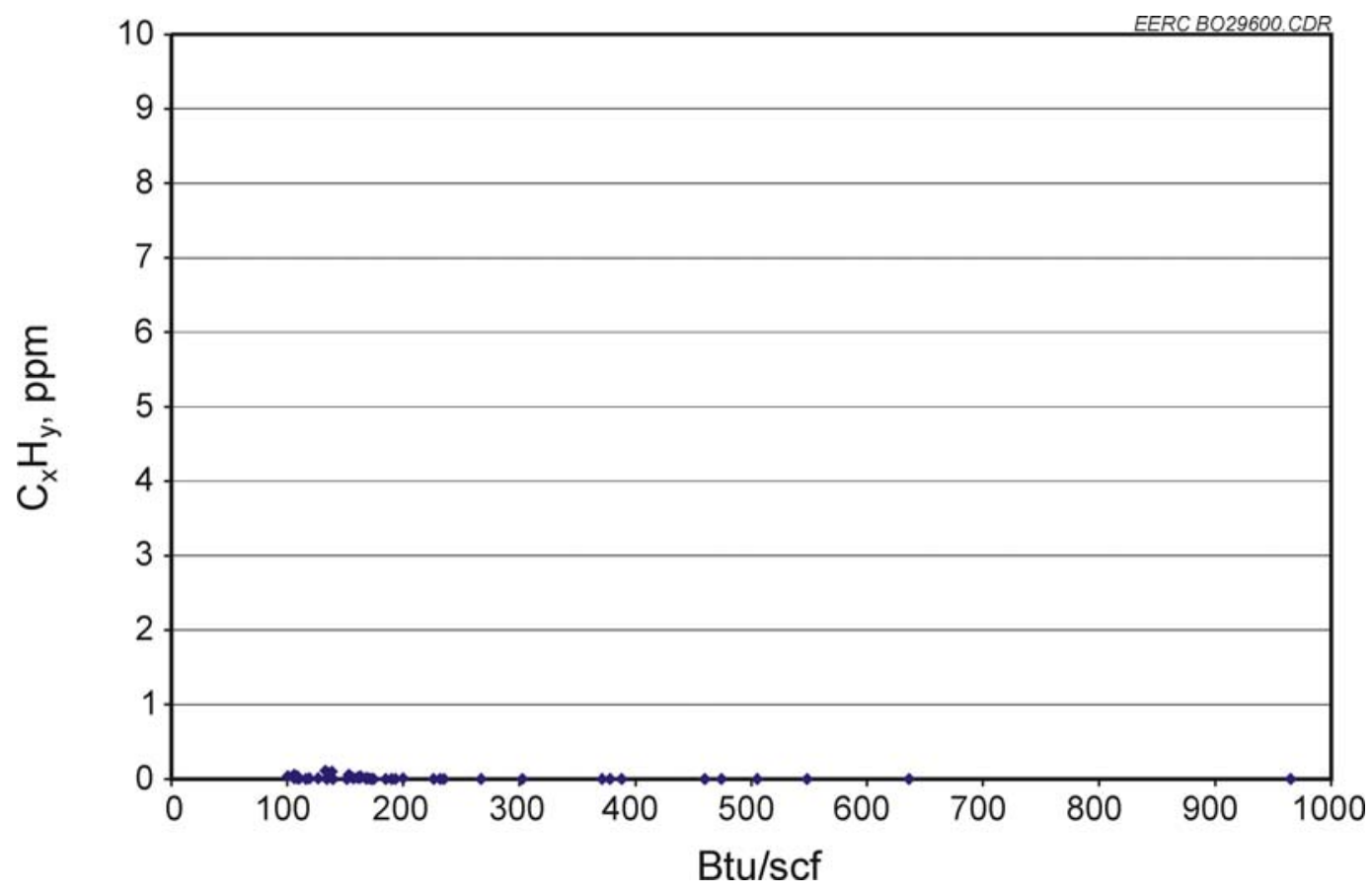

Figure 11. Unburned hydrocarbons remained below $0.2 \mathrm{ppm}$. 
A commercially available C30 microturbine was utilized to minimize error introduced by scaling bench scale results to full scale. FTIR measurements added validation to the flow rate method of determining gas energy content.

Calculations for start-up gas energy content assumed constant temperature in the outside storage tank. To minimize the temperature differential between the tank and house gas lines, the tank was completely purged with nitrogen to evacuate natural gas and achieve a uniform temperature.

\section{CONCLUSIONS}

Modifications allowed a microturbine to operate on gases below the manufacturer's $350 \mathrm{Btu} / \mathrm{scf}$ lower limit. The emission reduction benefit for $\mathrm{NO}_{\mathrm{x}}$ was better while firing low-Btu gas. Unburned hydrocarbons remained below $0.2 \mathrm{ppm}$, which is approximately 66 times less than the amount emitted by a small passenger car. CO levels increased when gas heating value dropped below $200 \mathrm{Btu} / \mathrm{scf}$. Adding a catalytic converter could alleviate this issue. Power production results were promising for low-Btu applications. The microturbine operated on $175 \mathrm{Btu} / \mathrm{scf}$ gas with a 13\% power derating and operated on $150 \mathrm{Btu} / \mathrm{scf}$ gas with a 33\% power derating. The microturbine ignited on $200 \mathrm{Btu} / \mathrm{scf}$ gas. Below $200 \mathrm{Btu} / \mathrm{scf}$, start-up gas will be required.

As environmental regulations continue to become more stringent, the energy sector will continue to alter its practices and processes to meet compliance. Burning low-Btu flare gas in a microturbine is a unique case where adding environmental control benefits both the environment and the company's bottom line. Typically, pollution control equipment costs are sunken costs that are incurred to allow continued operation. In contrast, microturbines pay for themselves in 2-3 years (8).

Modifications developed during this project will allow microturbines to operate on gases below the manufacturer's energy density specification. Oil fields with gas supplies less than $350 \mathrm{Btu} / \mathrm{scf}$ will benefit from modified microturbines.

\section{REFERENCES}

1. Compilation of Air Pollutant Emission Factors, Volume 1: Stationary Point and Area Sources; Nov 1998; Chapter 2.4.

2. Product Data Sheet. C30 Natural Gas Microturbine Performance Specifications. Capstone Turbine Corporation. 2006.

3. Capstone Turbine Corporation. www.capstoneturbine.com (accessed April 2007).

4. Flare gas graphic. www.netl.doe.gov/.../EP/ImprovedRec/flare.JPG (accessed April 2007). 
5. Welding graphic. biocrawler.com (accessed April 2007).

6. EPA Clean Air Act Title II. Emission Standards from Moving Sources; Section 202. Establishment of Standards. Light Vehicles. 1990.

7. Maricq, M.; Chase, R.; Podsiadlik, D.; Vogt, R. Vehicle Exhaust Particle-Size Distributions: A Comparison of Tailpipe and Dilution Tunnel Measurements; 1999; p 3.

8. Schmidt, D. Microturbine Application Reduces Sour Gas Flaring, Provides Partial Power. World Oil 2005, March. 
APPENDIX A

\section{SAMPLE CALCULATIONS}




\section{SAMPLE CALCULATIONS}

To convert actual flow (measured by rotameters) to standard flow:

$c f h \times \sqrt{\left(\frac{p s i_{g}+14.7 p s i_{g}}{14.7}\right) \times\left(\frac{530^{\circ} R}{T_{\text {actual }}+460^{\circ} R}\right)} \times F=s c f h$

Where:

cfh = actual cubic feet per hour

psi $_{\mathrm{g}}=$ gauge pressure, pound per square inch

${ }^{\circ} \mathrm{R}=$ degree Rankin

$\mathrm{T}_{\text {actual }}=$ actual temperature of gas

scfh $=$ cubic feet per hour at standard conditions

$\mathrm{F}=1.22$ for natural gas, 1.00 for nitrogen

To calculate a heating value for a mixture of natural gas (NG) and nitrogen $\left(\mathrm{N}_{2}\right)$ :

$\left(\frac{N G s c f h}{N G s c f h+N_{2} s c f h}\right)\left(\frac{965 B T U}{s c f h}\right)+\left(\frac{N_{2} s c f h}{N G s c f h+N_{2} s c f h}\right)\left(\frac{0 B T U}{s c f h}\right)=$ heating.value.of.mix

Where:

NGscfh = natural gas flow rate at standard conditions

$\mathrm{N}_{2} \mathrm{Scfh}=$ nitrogen flow rate at standard conditions

\section{To make a gas mixture with a certain heating value:}

Tank Volume $=500$ gal $=66.84 \mathrm{ft}^{3}$

The tank was pressurized by a compressor to $110 \mathrm{psi}_{\mathrm{g}}$. The following calculation converts actual tank volume at $110 \mathrm{psi}_{\mathrm{g}}$ to standard volume.

$66.84 \mathrm{ft}^{3} \times \frac{68^{\circ} \mathrm{F}+460}{40^{\circ} \mathrm{F}+460} \times \frac{110 p s i_{g}+14.7}{0 p s i_{g}+14.7}=598.8 \mathrm{scf}$

So, the $66.84 \mathrm{ft}^{3}$ of compressed gas equals $598.8 \mathrm{ft}^{3}$ of gas at standard conditions.

For a $200 \mathrm{Btu} / \mathrm{scf}$ fuel mixture, the mix must be 21\% natural gas and 79\% nitrogen (125.7 scf of natural gas and 473 scf of nitrogen).

To find at what pressure the $66.84 \mathrm{ft}^{3}$ tank will hold 473 scf of nitrogen: 
$473 \mathrm{ft}^{3} \times \frac{0 \mathrm{psi}_{g}+14.7}{\mathrm{X} \mathrm{psi} i_{g}+14.7} \times \frac{40^{\circ} \mathrm{F}+460}{68^{\circ} \mathrm{F}+560}=66.84 \mathrm{ft}^{3}$

$\mathrm{X}=84 \mathrm{psi}$

So, the tank must first be filled with nitrogen to $84 \mathrm{psi}_{\mathrm{g}}$.

The amount of natural gas required was $21 \%$ of 598.8 scf, or 125.7 scf.

$125.7 s c f \times \frac{40^{\circ} \mathrm{F}+460}{68^{\circ} \mathrm{F}+460} \times \frac{0 p s i_{g}+14.7}{110 p s i_{g}+14.7}=14 a c f @ 110 p s i_{g}$

To find how much volume the nitrogen takes up at 110 psig:

$66.84 f t^{3} \times \frac{84 p s i_{g}+14.7}{110 p s i_{g}+14.7} \times \frac{40^{\circ} \mathrm{F}+460}{40^{\circ} \mathrm{F}+460}=52.9 a c f @ 110 p s i_{g}$

Check to ensure the total gas in the tank at $110 \mathrm{psi}_{\mathrm{g}}$ is correct:

$52.9 a c f+14 a c f=66.9 a c f \quad$ Correct

The tank now contains a $200 \mathrm{Btu} / \mathrm{scf}$ gas mixture at $110 \mathrm{psi}_{\mathrm{g}}$. 
APPENDIX B

\section{RESULTS}




\section{RESULTS}

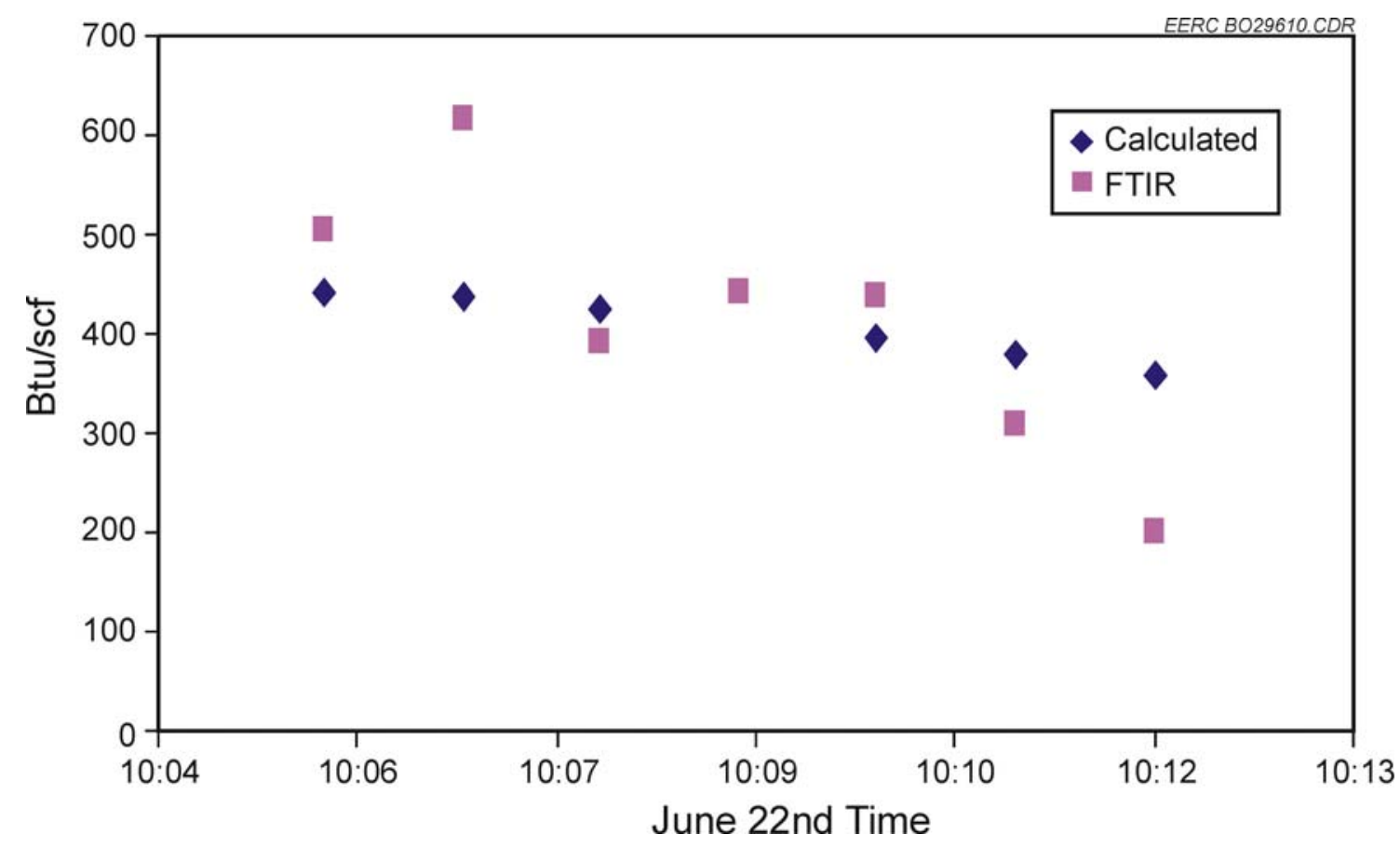

Figure B-1. FTIR measurements compared to Btu/scf calculations. Fuel index set at 11.

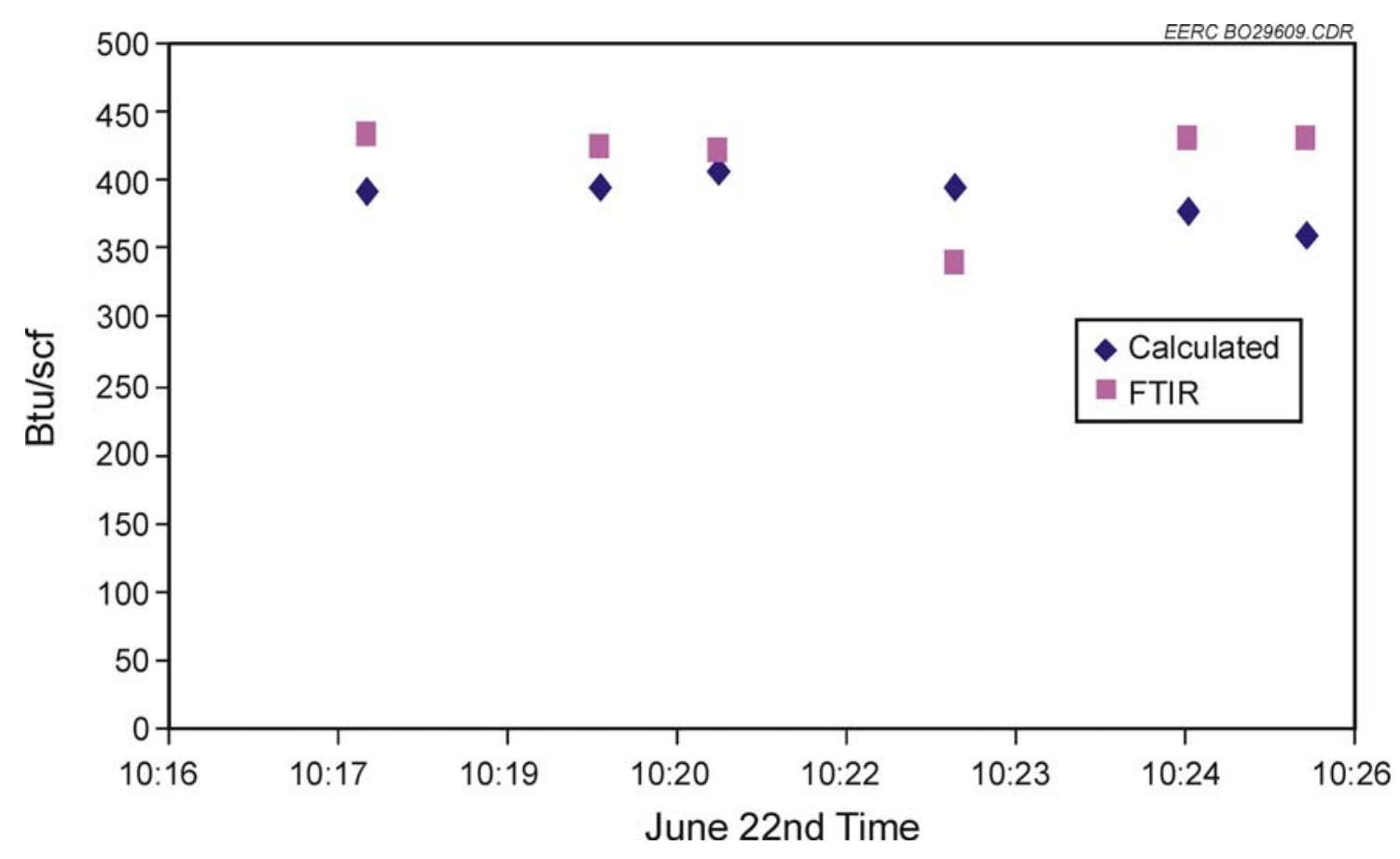

Figure B-2. FTIR measurements compared to Btu/scf calculations. Fuel index set at 14 . 


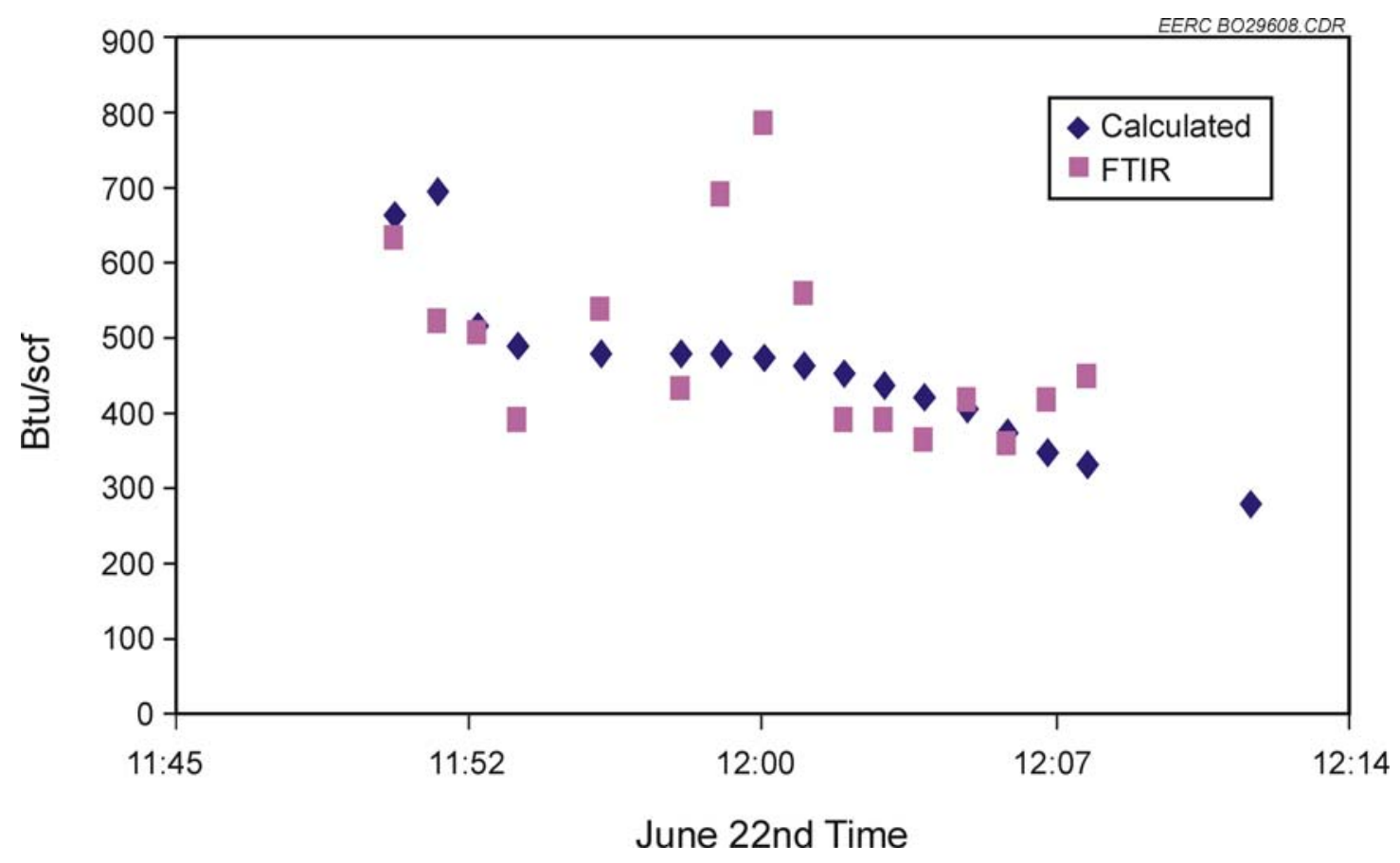

Figure B-3. FTIR measurements compared to Btu/scf calculations. Fuel index set at 11.

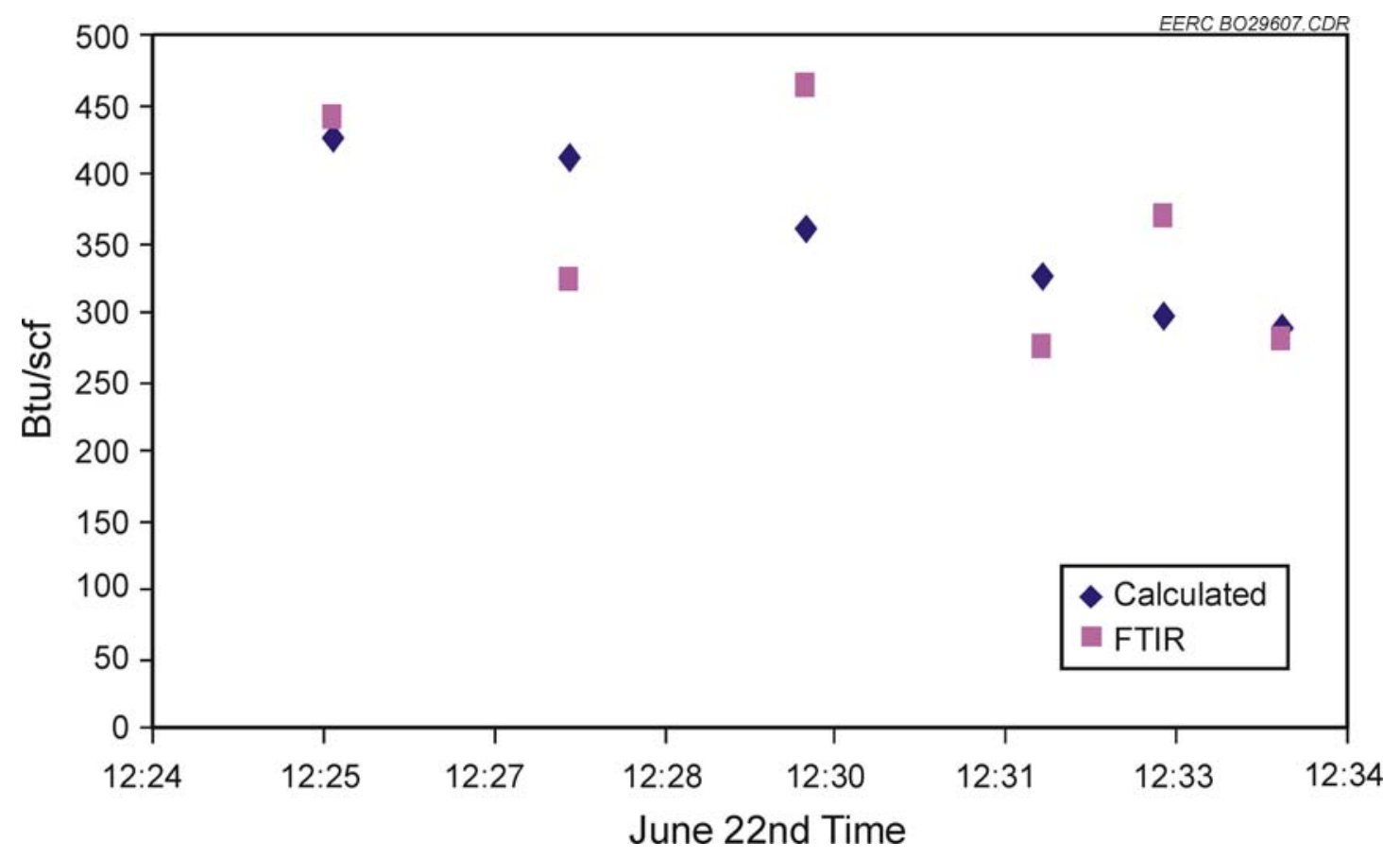

Figure B-4. FTIR measurements compared to Btu/scf calculations. Fuel index set at 14. 


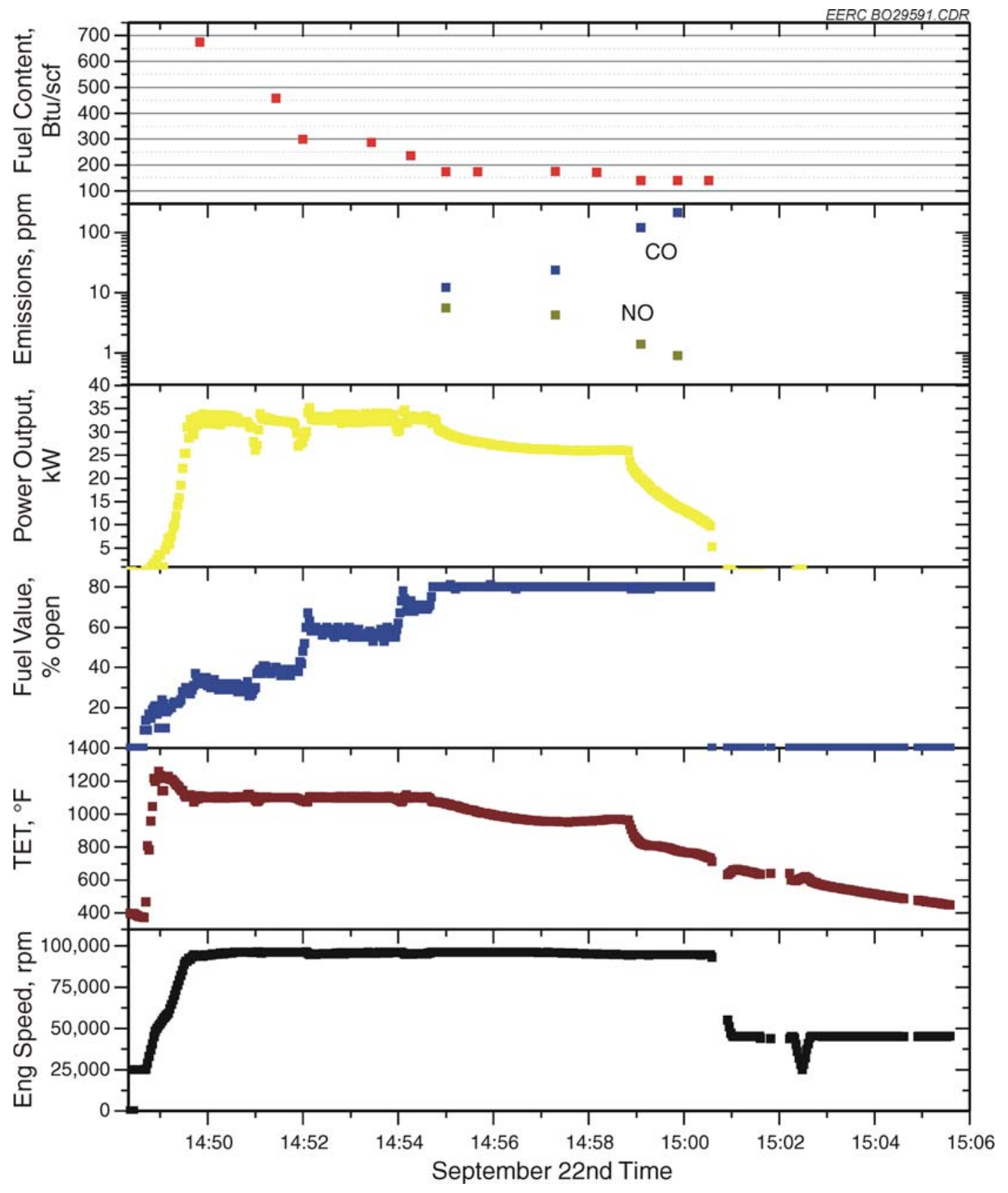

Figure B-5. First low-Btu test of second type of modified injectors. 


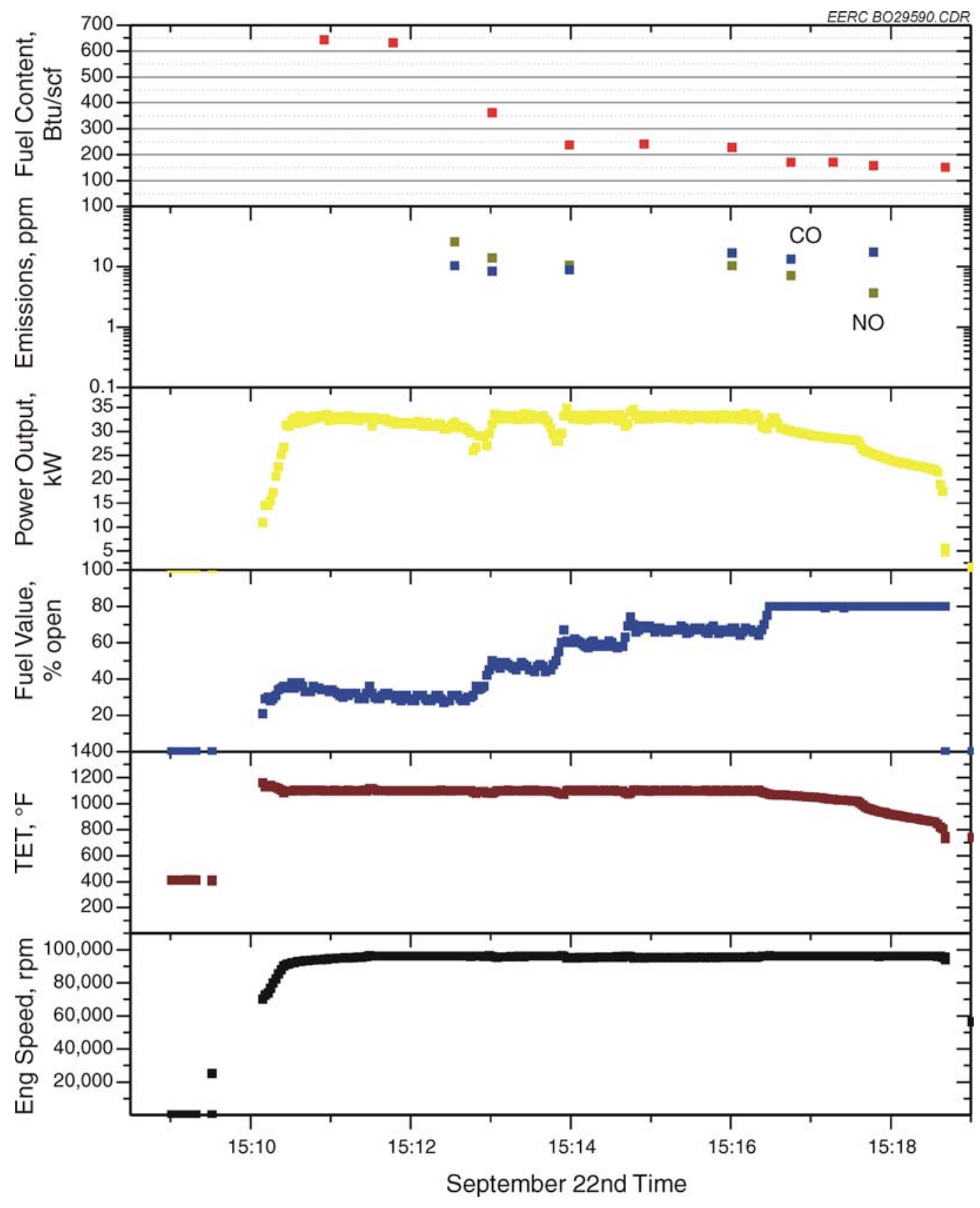

Figure B-6. Second low-Btu test of second type of modified injectors. 


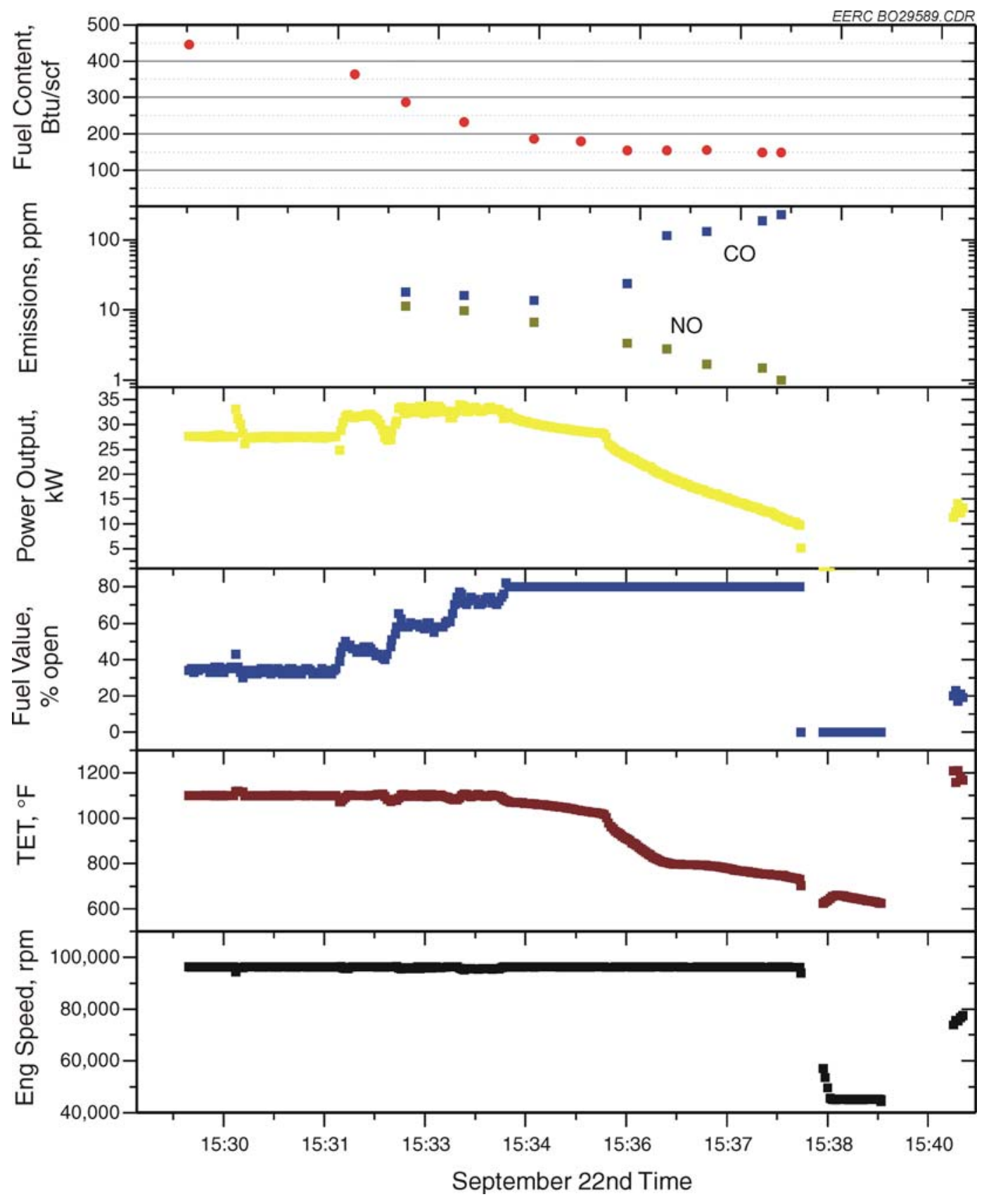

Figure B-7. Third low-Btu test of second type of modified injectors. 


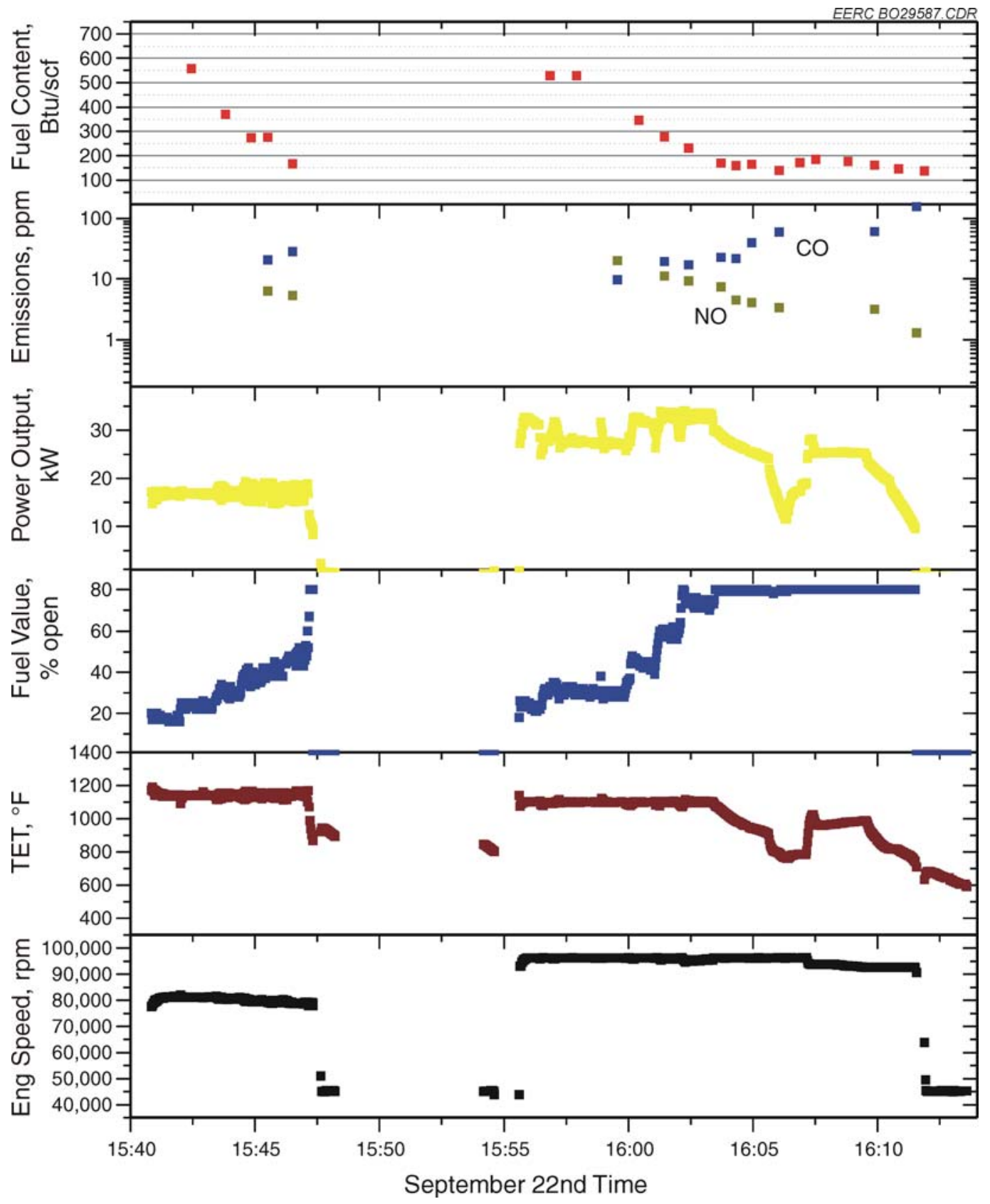

Figure B-8. Part load and fluctuating fuel content tests with second type of modified injectors. 


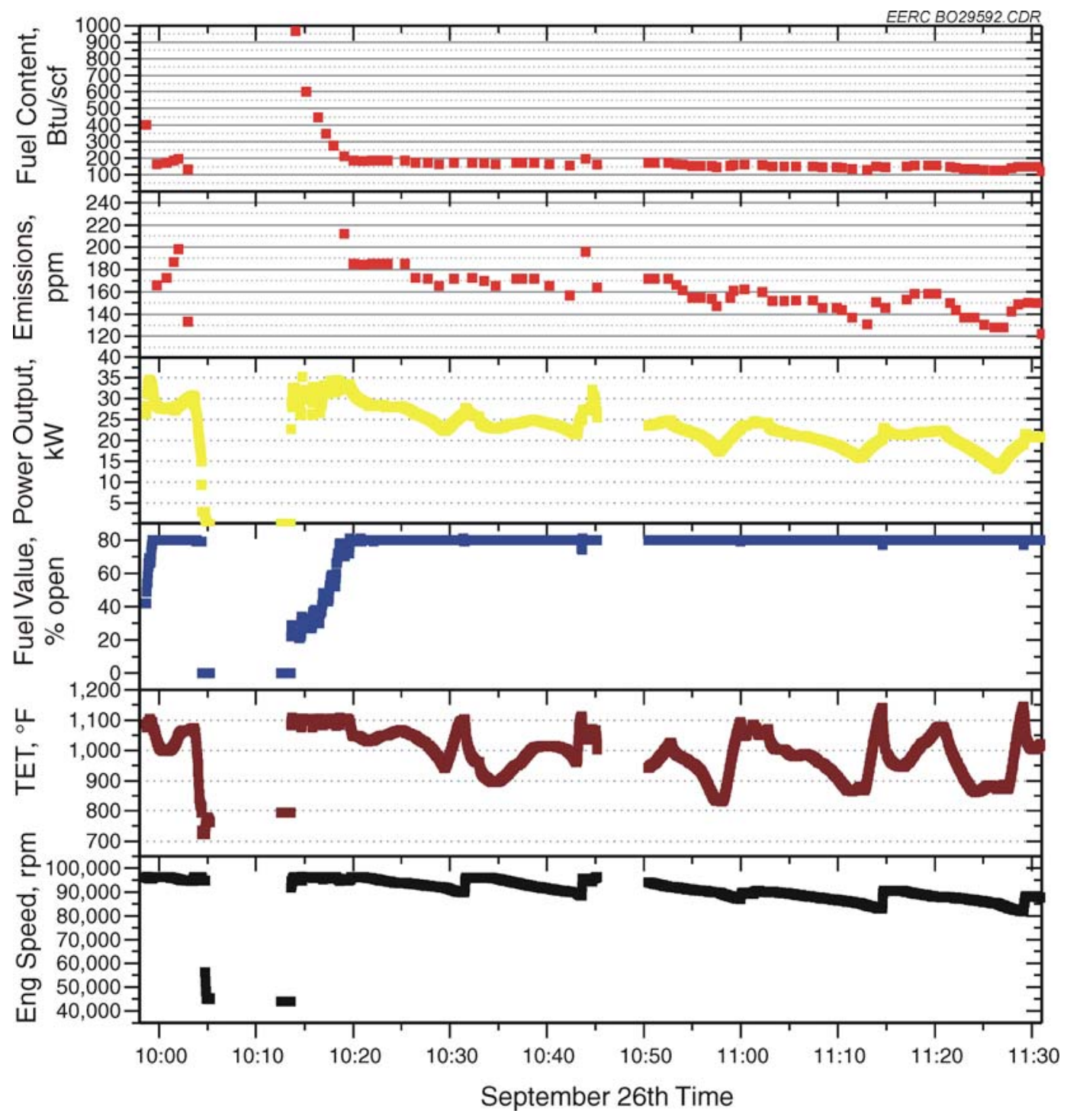

Figure B-9. Low-Btu testing with both modifications. Settings: low-Btu setting, power mode, $30 \mathrm{~kW}$ output, FI=14 (note: the top two graphs display the same information on different scales). 


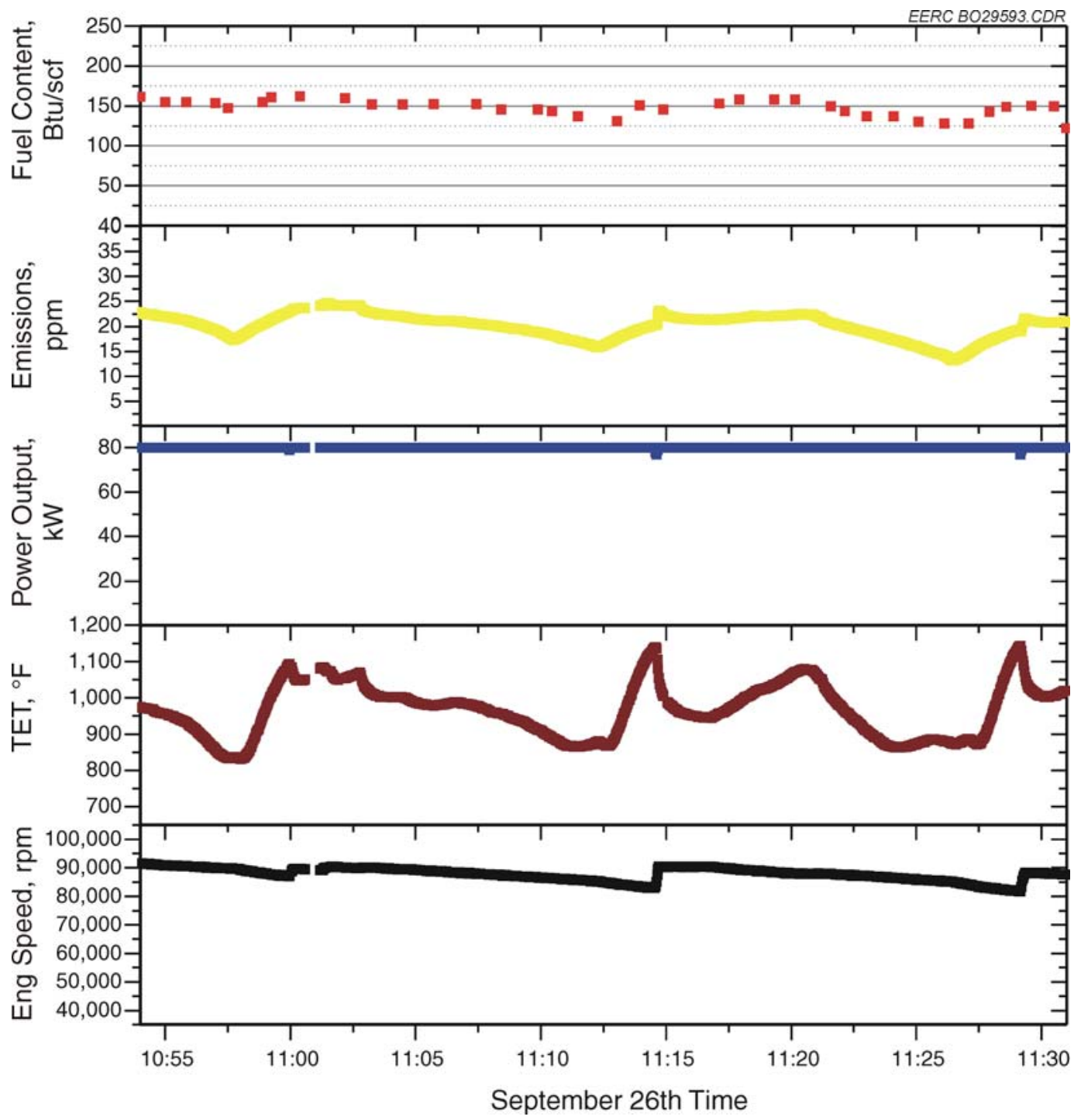

Figure B-10. During low-Btu testing with both modifications, the turbine produced $20 \mathrm{~kW}$ of power from $150 \mathrm{Btu} / \mathrm{scf}$ gas for 37 minutes. Settings: low-Btu setting, power mode, $30 \mathrm{~kW}$ output, $\mathrm{FI}=14$. 


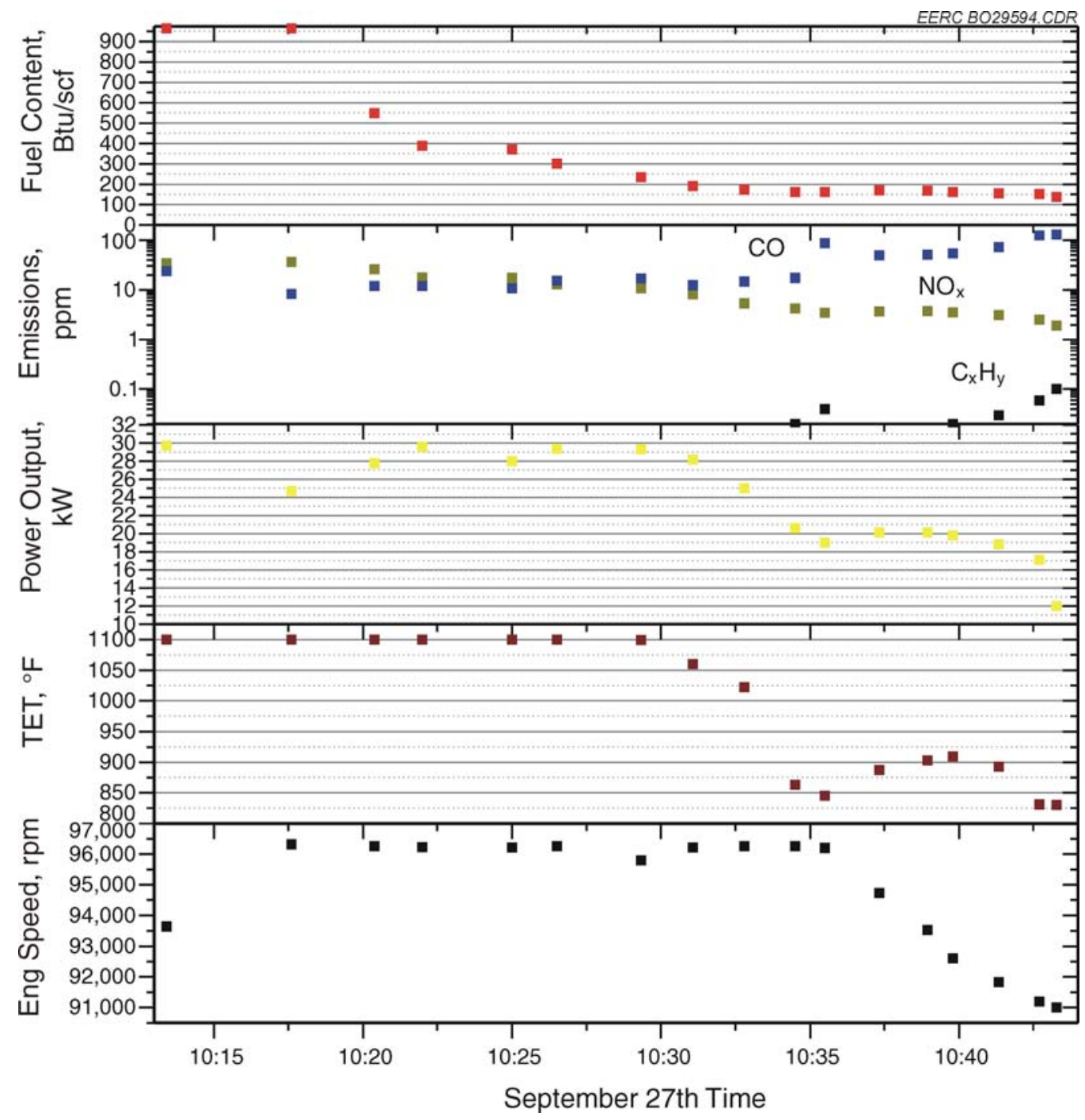

Figure B-11. Emissions when operating with both modifications. 


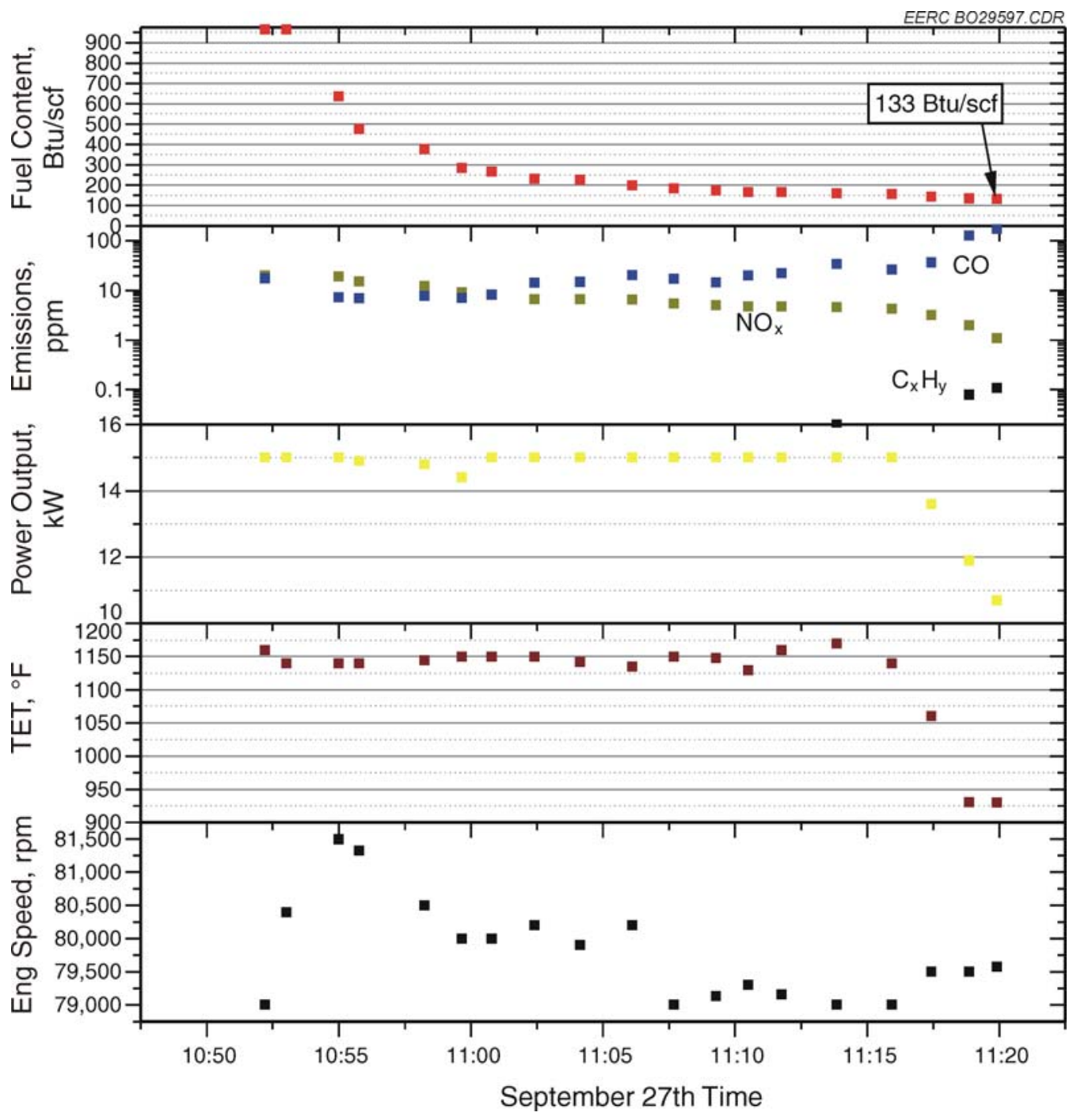

Figure B-12. Low-Btu testing with both modifications at partial load. Settings: Low-Btu setting, power mode, $15 \mathrm{~kW}$ output, FI=7. 


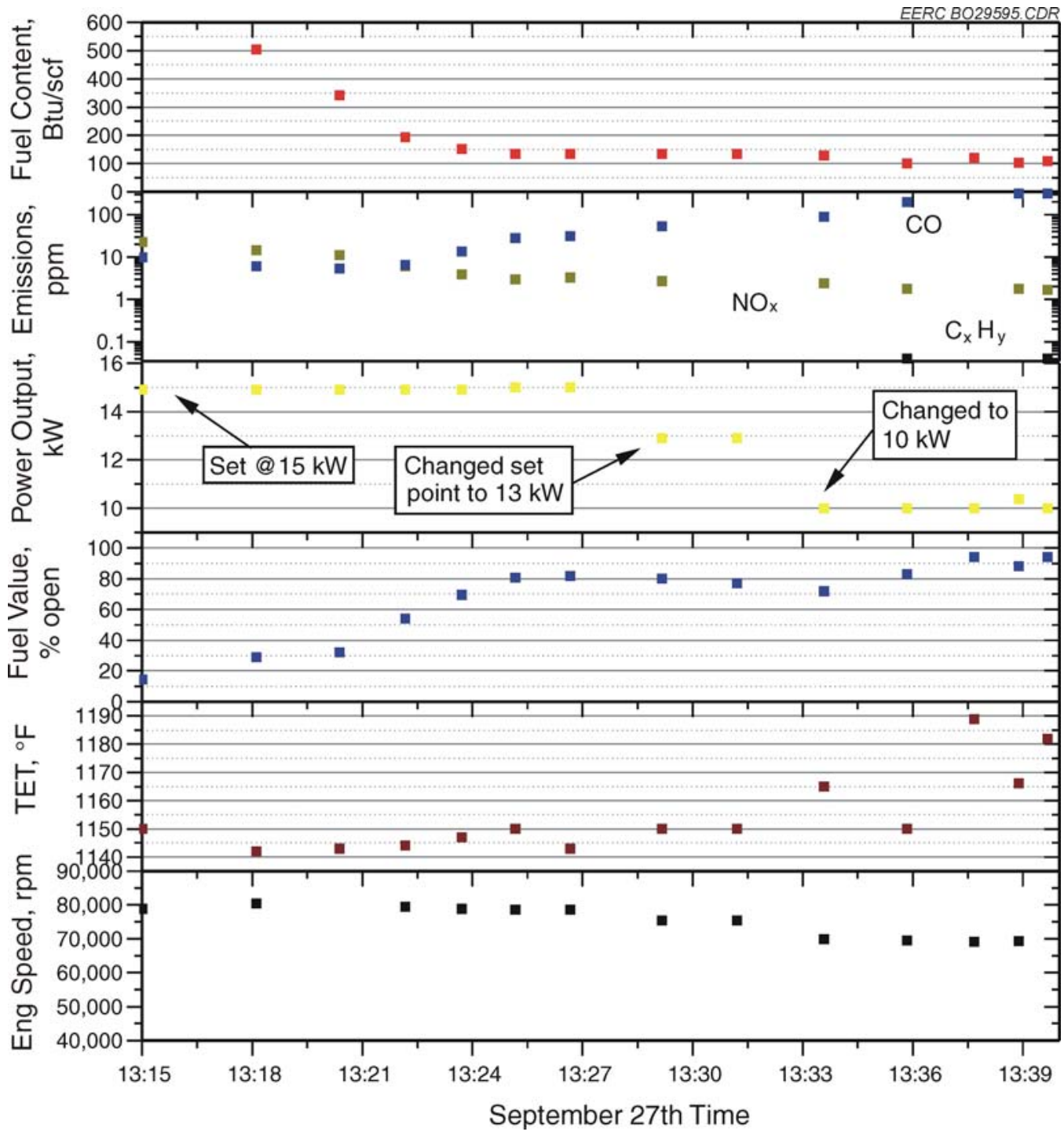

Figure B-13. Partial load tests with both modifications and varying power set point. Settings: Low-Btu setting, power mode, FI=14. 


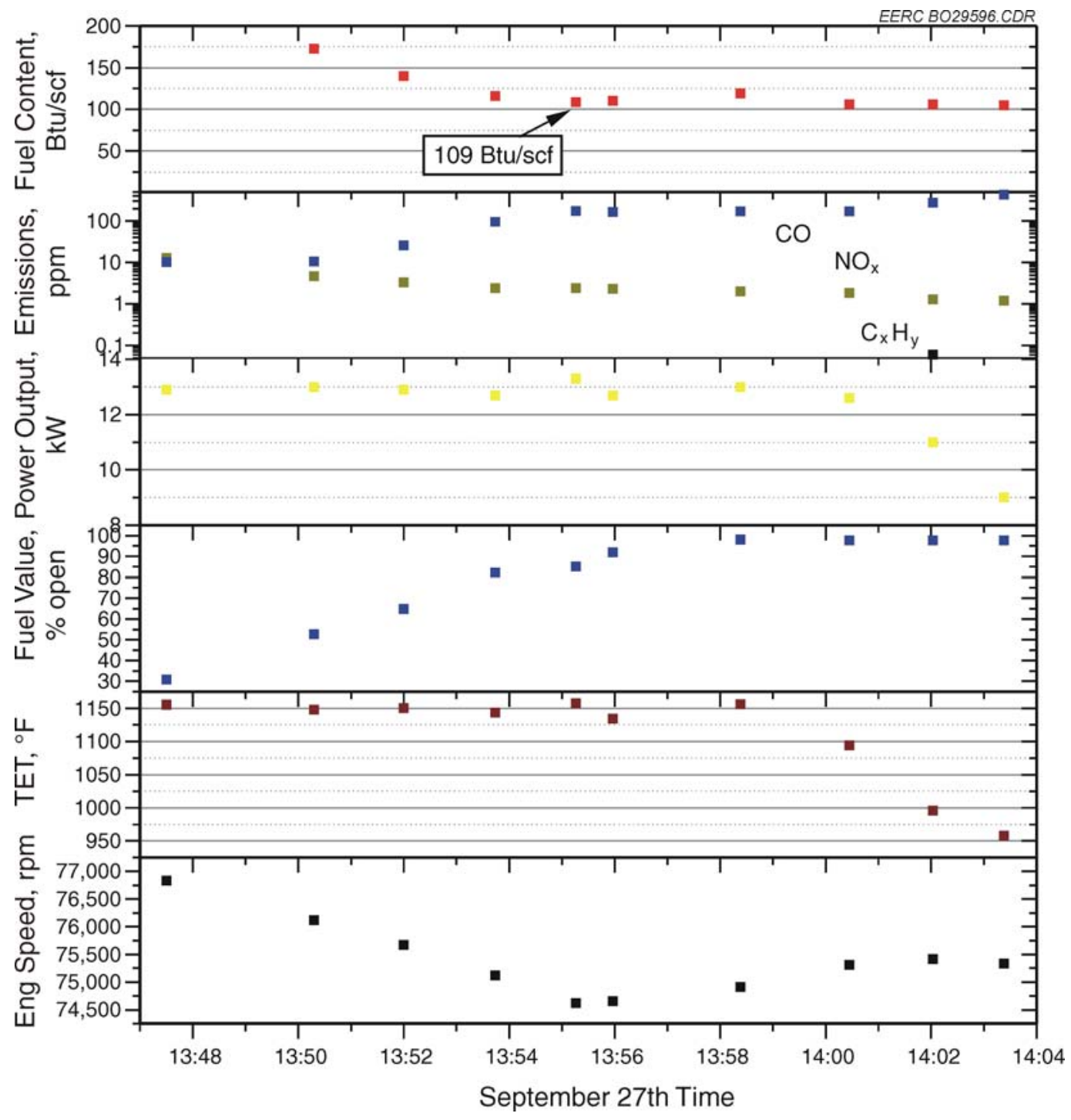

Figure B-14. Partial load tests with both modifications determined the minimum energy content while producing 13kW. Settings: Low-Btu setting, power mode, $13 \mathrm{~kW}$ power output, FI=14. 